\title{
THE SOUTH AFRICAN FIELD POST AND TELEGRAPH CORPS (1914-1915)
}

\section{INTRODUCTION}

\section{a. Before the formation of the Union}

Three hundred and seventy years separate the reader from 7 th July, 1501, the day on which the Portuguese mariner Joao de Nova, landed at Mosselbay to place a letter in an old shoe in the hope that one of his countrymen would visit the "Post Office Tree" and would find and read this - the oldest known postal article of our country's history'.

Of more recent date are the "Post Office Stones," engraved in the vicinity of Table Bay, a number of which are kept in the South African Museum, Cape Town'2.

After the establishment of the Refreshment Station at the Cape in 1652 and the beginning of gradual colonization, unofficial postal articles were entrusted to personal messengers or passing travellers for delivery ${ }^{2}$, whilst the Dutch East India Company had its own official messengers.

In 1871, "Post Holders" were equipped at Simonstown, Saldanha Bay and Robben Island by the Company and on 28th December, 1791, the first Post Office, with Adriaan Vincent Berg as first Postmaster and A. B. Ziervogel as first postman, was opened in Cape Town ${ }^{3}$.

The appointment of the first South African Postmaster General dates back to 1798; the Post Office was situated in the Castle4.

In 1833 there were twenty-one Post Offices in the Cape Colony. The first mailcoach service was established in 1843 between Cape Town and Swellendam ${ }^{6}$, whilst the first Cape stamps were issued on 1st September, 1853.

a. In the publication Runner and Mailcoach the development of the civilian Postal Services of the Cape Colony, as well as that of Natal and the Boer Republics, can be traced', while an organised Military Postal Service existed during the Anglo-Boer War on Boer and British sides .

\section{b. After the formation of the Union}

On 31st May, 1910 the Department of Posts and Telegraphs of the Union of South Africa, was established. Existing legislation regarding the four provinces, remained operative until 1st September, $1911^{9}$.

On this date the Act to Consolidate and Amend the Laws in force in the Union relating to the Post Office and to impose certain charges to discourage Shipping Combination, with a short title Post Office Administration and Shipping Combinations Discouragement Act, 1911 (Act No. 10, 1911) ${ }^{10}$ came into force.

To give the reader an idea of the extent of the services rendered by the Department in 1913, the following particulars are provided: 
i. Number of Post and Telegraph Offices .............................

ii. Number of letters posted in the Union (including Basutuland)

100579000

iii. Number of postcards

18544864

iv. Number of newspapers

v. Number of printed papers

vi. Number of books and samples (parcels)

vii. Official correspondence

ix. Registered articles

\section{Total}

$176763548^{\prime \prime}$

Concerning the telegraph service in 1913 the following particulars apply:

i. Number of Telegraph Offices:

Post Office

ii. Number of telegrammes (including radiogrammes) handled

During the course of the following year World War I broke out. Britian's declaration of war caused all the other parts of the then British Empire, and also the Union of South Africa, to enter into a state of war. At the same time the Prime Minister, Genl. L. Botha, was requested by the British government to invade German South-West Africa.

This decision led to unrest in the Union and on 12th October, 1914 martial law was proclaimed and the Rebellion broke out. In January, 1915 the Rebellion was suppressed and General Botha commanded the Union forces in South-West Africa $^{13}$. It will be remembered that the operations against this area already commenced in September, 1914. On 18th September, 1914, Luderitz Bay was occupied by Col. P. S. Beves with more than 1800 men, after about 2400 troops had gone ashore at Port Nolloth on 1st September, 1914'.

On 27th September, 1914 a detachment of the latter force was defeated at Sandfontein ${ }^{15}$.

Although, as a result of the Rebellion, the campaign against German South-West Africa was not completely paralysed, the real campaign only commenced in January, $1915^{16}$.

Wherever the activities of the military postal service, etc., in the field are dealt with in this summary, it should be borne in mind that the course of events described, also had its effect on the South African Field Post and Telegraph Corps, which consisted of a postal and a signals section.

The following particulars pertain exclusively to the Postal Division of the Corps:

\section{1 \\ ORIGIN, FUNCTION, ORGANIZATION AND FIRST INSTRUCTIONS}

a. Origin

Under the powers vested in him in terms of sub-section (3) (b) of section 28 of Act No. 13 of 1912 (South African Defence Act, 1912), the Governor-General, by Government Notice No. 1630, of 30 September, 1914, established the South African Field Post and Telegraph Corps, which consisted of a Signals and Postal Division, with an establishment of 500 (300 for the former, and 200 for the latter section), as an Active Citizen Force unit during the period of hostilities in South Africa. 
On the same day the Governor-General by Government Notice No. 1631, granted permission for the temporary detachment of members of the Natal Telegraph Corps and the Transvaal Signalling and Field Telegraph Company to the newly established unit.

On 28th August, 1914, Maj. Edward Albert Sturman, born on 24th October, 1864, later Lt.-Col. E. A. Sturman, C.B.E., was appointed Director of Postal Services, South African Postal Corps and transferred to the South African Field Post and Telegraph Corps on 30th September, 1914. From 20th September, 1914 till 30th September, 1915, Maj. Sturman rendered service in connection with South West Africa; on 1st October, 1915 he was released from his Military Post Office duties to attend to the South African Gifts and Comforts Organization".

On 22nd August, 1918 the London Gazette announced that Maj. Sturman had been awarded the M.B.E. and on 15th April, 1919 his transfer to his military section of this order was announced in the same official publication. After ceasing to be on active service on 1st October, 1918, Maj. Sturman joined the Reserve of Officers on 17th March, 1920 with the rank of Major, and was transferred to the South African Corps of Signals, A.C.F. His promotion to the rank of Lieutenant-Colonel followed on 9th November, 1923 and on 11th May, 1923 his military career came to an end. A day before Maj. Sturman joined the Service, Capt. F. Victor R. Romilly was appointed as assistant director and censor in the field and rendered service until 29th July, 1915 ${ }^{18}$.

By virtue of these appointments the command of the Corps received early attention while the experience gained during the Anglo-Boer War, served as a guide in the appointment of additional personnel to Section 2 of the Corps ${ }^{19}$.

\section{b. Function}

The function of the military postal service was described by Lt.-Col. P. J. Pyper, Assistant Director, Army Postal Services, East Africa Command, during or shortly after the Second World War, in an undated publication, i.e. The Army Postal Service in War, as follows:

The function of the Army Postal Service is primarily to maintain the efficient and expeditious postal communication between the home country and the land and air forces in the field necessary to the well-being of the troops.

He continues:

The importance of a letter from home to a soldier in the field is as great if not greater than food. A soldier would gladly forego satisfying his physical hunger if he knew that by doing so his hunger for news from home would be satisfied. An Army marches on its stomach - a full stomach - but no matter how full a soldier's stomach may be, the morale falls to zero when he does not regularly receive news from home.

Lt.-Col. Pyper adds:

We have learned from experience that the psychological effect of news from home is the winning of battles. This claim is intended not to minimize the importance of other essential military services, but rather to of things. Mails, supplies, etc., are things which "must get through" to emphasise the vital importance of a letter to a soldier in the big scheme 
troops in every circumstance and regardless of financial cost - if they are to contribute fully towards the making of a whole, a team, a conquering force...

c. Organisation

In order to serve its purpose in the most efficient manner the organisation of the Corps was planned and implemented as follows:

i. Headquarters. General Post Office, Cape Town. Station of Maj. A. E. Sturman, previously acting Secretary, Department Posts and Telegraphs, now Director Postal Services. Commanding Officer of the 2nd (Postal) Division of the Corps.

ii. Base Post Offices. On 23rd September, 1914 the following Base Post Offices wre in operation: Base No. 1 (Cape Town), Base No. 2 (Port Nolloth), A-Force; Base No. 3 (Upington), B-Force; Base No. 4 (Lüderitzbucht), C-Force; Base No. 5 (Swakopmund), D-Force ${ }^{20}$.

iii. Advance Base Post Offices. On 23rd September, 1914 the following Base Post Offices were in operation: No. 2 Advanced Base Post Office (Port Nolloth), No. 3 Advanced Base Post Office (Upington), No. 4 Advanced Base Post Office (Lüderitzbucht), No. 5 Advanced Base Post Office (Swakopmund) ${ }^{21}$.

iv. Field Base Post Offices.

v. Field Post Offices. In regard to these Post Offices it was decided that Commanders of Advanced Base Post Offices had to provide adequate Post Office facilities in the field in consultation with commanders of the Forces. Where necessary, non-commissioned officers or privates of the Corps could be assigned to specific stations as determined by commanders of columns. Wherever possible, Field Post Offices had to be established at points where Post Offices had existed previously in German South West Africa ${ }^{22}$.

\section{d. First Instructions}

On 30th September, 1914 the serving Director Army Postal Service, Maj. E. A. Sturman, issued the following general instructions in Circular No. 1 concerning the different Military Post Offices, the handling of incoming and outgoing mail, matters pertaining to postage stamps, postal orders, postcards, private correspondence of troops, re-dispatch of postal articles, censorship, the handling of postbags, taking possession of buildings in the occupied territories, etc.

ARMY POST OFFICE CIRCULAR NO. 1

General instructions to be observed by members of the South African Postal Corps.

\section{BASE POST OFFICE}

The Officer in charge of Base Post Office, Cape Town will be responsible for the organisation of that office.

\section{ADV ANCED BASE POST OFFICE}

The Officer in charge of Advanced Base Post Office, Cape Town will be responsible for the forwarding of closed mails to Field Post Offices and to the Base, for making the necessary arrangements for the sorting and distribution of cross post correspondence, for the collection and due 
the Director of Postal Services all information obtainable affecting units in the Field for which the Army Post Office is expected to make provision. All demands for transport for the distribution of mail matter to columns must be made direct to the Deputy Assistant Quartermaster General (D.A.Q.M.G.) of each Base concerned.

\section{N.C.O.'S IN CHARGE OF FIELD POST OFFICES}

The N.C.O. (Non-Commissioned Officer) in charge of a Field Post Office or detailed for duty with a Column is responsible for the receipt and distribution of the mails for the Troops served by his particular office, for the preparation and despatch of outward mails to the Base and Advanced Base Post Office, for ascertaining fuiure addresses from the staff and advising the Base Office and Field Base Post Office, for the sale of stamps and Postal orders, registration of letters, for the transaction of such other kinds of Postal business as may be authorised from time to time.

\section{INW ARD MAILS}

Correspondence for the Forces in the Field will be sorted as far as possible at Base Post Office No. 1, Cape Town, into unit bundles or bags, according to information supplied from time to time.

On arrival at Advanced Base Post Offices, mails will be checked to see that seals are in order and, after opening and contents to be found in order, will be sorted to local arrangements.

Correspondence for Field Post Offices will be resorted and forwarded by first available opportunity and the registered letter and parcel entries, transferred to the Letter Bill covering the despatch.

\section{OUTW ARD MAILS}

Outward mails will follow the course as described in the previous paragraph, but in reverse direction, except that All outward correspondence must first pass the Field Censor.

\section{REGISTERED ARTICLES}

Registered articles will be checked and treated in the same manner as in practice in the Civil Post Office and as far as possible, the hand to hand check must be rigidly enforced.

Registered articles for Units situated some distance from a recognised Field Post Office may be handed over to the Post Orderly of that Unit, who must give a receipt for same on P.71 Registered Letter List Book.

\section{PARCELS}

Inland parcels (Parcels originating within the Union of South Africa) must be advised and treated in the same manner as applies to the civilian Post Office, parcels delivered to Post Orderlies to be handed over in the same manner as registered articles and receipt taken on Parcel List Book.

POST AGE ST AMPS, ETC.

Every Field Post Office must hold a credit stock of Postage stamps, Postal orders, Postcards, registered letter envelopes, and stamped envelopes, suth credit to be decided according to estimated demand. No alteration of this amount may be made without reference to the Director of Postal Services. Postal orders may be cashed, when sufficient coin is on hand to admit of same being done, and the paid orders remitted by first post together with requisitions for further supplies of stamps or postal orders. 
Cash resulting from stamp and Postal order sales should, whenever possible, be handed over to Field Paymasters with Columns, in exchange for Regimental or other cheques. On no account may private cheques be exchanged for cash.

Under no circumstances may officers in charge of Advanced Base or Field Post Offices, part with stamps or postal orders to anyone attached to Columns, for the convenience of troops unable to touch at such Post Offices, unless cash in payment therefore is passed, to cover such transactions.

These instructions not only show the internal organisation of the Corps but also give an insight into the activities as regards both liaison with the Civilian Postal Administration and liaison with the Quartermaster General, Union Defence Force ${ }^{23}$.

\section{2 \\ DEVELOPMENT OF ACTIVITIES IN 1914}

a. Post Offices

On 23rd September, 1914, according to Order No. 1, as issued on the same date by Maj. E. A. Sturman, Director South African Postal Services, the following Base Post Offices existed: No. 1, Cape Town; No. 2, Port Nolloth (A. Force); No. 3, Upington (B-Force); No. 4, Lüderitzbucht C-Force). Although the establishment of Base Post Office No. 5, Swakopmund, was simultaneously announced in respect of the D-Force, Order No. 2 of 30th September, 1914, stated that the establishment of this Base Post Office has been postponed.

As there was suggestions of delay in postal delivery overland from Cape Town to No. 2 Base Post Office (Port Nolloth), instructions were issued for the moving of this Post Office to Steinkopf. This move was implemented on 26th September, 1914 and the necessary instructions were issued to eliminate delays in postal delivery. In order to remain abreast of the activities of these offices, an order was issued on 7th October, 1914 for the commanders of Base Post Offices 2, 3 and 4 to draw up weekly reports.

On the same day it was announced that the Headquarters in Cape Town was to be advised immediately by telegraph in the event of the opening or closing of Field Post Offices.

The first two Field Post Offices were opened on 15th and 16th October, 1914, respectively at Prieska and Port Nolloth. On 23rd October, 1914, commanders of Advanced Base Post Offices were instructed to make arrangements for adequate post office facilities in the field, in consultation with commanders in the field. As already indicated above, it was furthermore laid out that, if necessary, non-commissioned officers or privates of the Corps could undertake such activities at points indicated by commanders of Columns. On the other hand it was also stressed that Field Post Offices should, wherever possible, be situated in existing Post Office premises in German South-West Africa.

One day before these instructions were issuled, a number of supporters of Maj. (temporary Lt.-Col.) S. G. Maritz came to blows with a small detachment of Government troops at Keimoes, whilst Union Defence Force troops were defeated during a skirmish at Sandfontein by a 
superior German force. These events, preceded by Brig.-General C. F. Beyers' resignation as Commandant General, Active Citizen Force, led to the consolidation of the Union Defence Force's position in respect of German South-West Africa on the one hand, and to operations of Government troops in the Transvaal, the Orange Free State and North West Cape, on the other hand ${ }^{24}$.

The fullowing post office moves must accordingly be seen in this light: On 25th October, 1914 No. 2 Advanced Base Post Office was moved from Steinkopf to Port Nolloth. On 26th October, the Field Post Office, Prieska, was moved to Marydale and on 28th October, 1914, to Kenhardt. On 27th and 30th October, 1914, Field Post Offices were opened respectively at Kakamas and Birdfield, while No. 5 Advanced Base Post Office commenced operations in Pretoria on 28th October, 1914.

Two days later, the acting Postmaster General informed the Quartermaster General that arrangements had been made to open an Army Post Office in Johannesburg to serve members of the Union Defence Force who were on active service in the Transvaal at that time. The following Field Post Offices operated briefly between 2nd November and 5th November, 1914:

Field Post Office, Birdfield, closed 2nd November, 1914.

Temporary Field Post Office, Kraaifontein, opened 2nd November, 1914, closed 4th November, 1914.

Field Post Office, Kenhardt, closed 4th November, 1914.

Field Post Office, Bloemfontein, opened 5th November, 1914. On the same day the move of No. 5 Advanced Base Post Office from Pretoria to Johannesburg was announced.

Other changes during November, 1914 were the following:

Field Post Office opened at Steinkopf, 6th November, 1914.

No. 2 Advanced Base Post Office, moved from Port Nolloth to O'okiep on 9th November, 1914 and on 2nd December, 1914 to Steinkopf.

No. 1 Field Post Office opened at De Aar, 16th November, 1914.

No. 2 Field Post Office opened in the Orange Free State, 16th November, 1914.

The civilian post office at Kimberley handled Army Post Office correspondence from 16th November, 1914.

A civilian post office opened at Booysen's Camp on 17th November, 1914.

No. 2 Field Post Office, Orange Free State moved to Beaconsfield on 19th November, 1914, and then to Upington on 23rd November, 1914, from which date it was placed under control of No. 3 Advanced Base Post Office.

A temporary Field Post Office opened at Slabberts, Orange Free State on 26th November, 1914 and on 27th November, 1914 the following were informed there of: Col. Cmdt. Botha, Kroonstad; Col. Botha, Harrismith; Col. Cmdt. Badenhorst, Ventersburg; Col. Cmdt. Celliers, Bultfontein; Lt.-Col. Fouche, Senekal; Brig.-Genl. T. H. Lukin, Bloemfontein; Col. Cmdt. Smuts, Bethlehem; Col. Cmdt. van Deventer, Heilbron and Lt-Col. Enslin, Kroonstad.

No. 2 A Field Base Post Office was moved from Bloemfontein to Kroonstad on 30th November, 1914 and was replaced in Bloemfontein on 1st December, 1914 by No. 3 Field Post Office. 
In December, 1914 the following changes took place:

No. 4 Field Post Office opened in Bethlehem on 1st December, 1914.

An Army Post Office was also established in Walvis Bay on 26th December, 1914.

In a letter dated 11th December, 1914, the Quartermaster General mentioned, interalia that all commandos in the Transvaal and the Orange Free State would in all probability be disbanded in the near future and that the special service arrangements in connection with the Military Postal Service effecting such commandos would then fall away.

According to a letter written by Maj. Sturman to the Quartermaster General on 17th December, 1914, the organization of the Army Post Office, at that time, was as follows:

i. No. 1 Base Post Office, Cape Town.

ii. No. 2 Field Base Post Office, Headquarters at O'okiep, with a Field Post Office at Steinkopf for the areas of Port Nolloth, Springbok, Pella and Ramansdrift.

iii. No. 3 Field Base Post Office, Headquarters at Upington, with a Field Post Office at Kakamas to serve Keimoes and district.

iv. No. $2 A$ Field Base Post Office, Headquarters at Kroonstad, with a Field Post Office at Bethlehem and Kroonstad, to serve the mobile forces in the Orange Free State.

v. No. 4 Field Base Post Office, Lüderitzbucht, German South-West Africa.

v. No. 5 Field Base Post Office, Johannesburg.

vii. No. 1 Field Post Office, De Aar, used for exchange and as a stores depot.

viii. An unspecified number of Field Post Offices that were opened to fulfil temporary needs and were closed again.

ix. The Military Section under civilian control, Kimberley, to serve units operating in that area.

b. Personnel

On or about 16th November, 1914, the day on which No. 1 Field Post Office was opened at De Aar, the personnel strength of the Corps, with an indication of the Corps numbers of the members concerned, was as follows:

Headquarters, Cape Town: Maj. E. A. Sturman (1), Maj. J. A. Venning (2), Serg. V. R. Woods.

No. 1 Base, Cape Town

Lt. J. F. Kierney (10), Company Serg.-Maj. J. Pollock (14), Company Serg. Quartermaster A. Colenso (12), Cpl. H. C. Smith (19), Cpl. A. J. Dawson (22), Cpl. A. W. Goldie (20), L./Cpl. A. J. Hampson (21), L./Cpl. C. J. Conway (36), L./Cpl. H. Hembury (43), Private J. Morison (4), L./ Cpl. G. J. Sumption (50), L./Cpl. R. C. Isemonger (51), L./Cpl. H. W. Willmer (52), L./Cpl. A. MacLachlan (60), L./Cpl. R. McIntyre (61). 
No. 2 A Base, Steinkopf:

No. 2 A Base, Bloemfontein:

No. 3 Base, Upington:

No. 4 Base, Lüderitzbucht:

No. 5 Base, Johannesburg:

No. 1 Field Post Office:
Capt. F. V. R. Romilly (5), Serg. H. H. Murphy (15), Cpl. A. V. Stanley (37).

Lt. C. Wannell (6), Cpl. W. J. Maloney (23), L./Cpl. W. R. Portingale (41), L./Cpl. A. E. de Gruchy (42), L./Cpl. W. F. Moon (53), L./Cpl. D. Thompson (57), L./Cpl. J. Carver (58), L./Cpl. E. J. Palmer (59).

Capt. J. W. French (3), Lt. E. Leslie (7), Lt. J. A. Rademan (9), Serg. C. A. Sweet (35), L./Cpl. H. E. Duck (24), L./Cpl. H. J. Antoncich (25), L./Cpl. A. W. Matthews (26), L./Cpl. E. F. Barry.

Capt. H. Frew (4), Lt. J. R. Howitson (8), Serg. A. C. Stanley (17), Cpl. W. J. Davies (32), L./Cpl. G. R. O’Connor (33), L./Cpl. T. H. Fox (34).

Lt. F. Robinson (11), Serg. L. J. Allen (44), Cpl. A. V. Jeffrey (45), L./Cpl. F. W. Andreas (46), L./Cpl. J. H. Norwell (47).

De Aar: Serg. W. M. Milne (39), L./Cpl. W. S. Potter (48), L./Cpl. P. J. Henchie (47), L./Cpl. S. J. Snashall (56).

\section{c. Delivery Problems}

One of the problems that arose during the first months of the existence of the Corps was the delivery of mail to members of Government commandos during the Armed Protest and the period of Rebellion that followed. From the available information the mobile Government commandos appeared to have been difficult to reach at times, since they often changed their locations in the Transvaal and the Orange Free State at intervals.

In order to give some guidance to sorting personnel serving at Base Post Offices, the Quartermaster General on 30th October, 1914 provided two lists of commandos operating in the North West Cape and the Transvaal to facilitate delivery of letter post and telegrammes to the Corps, as well as to the Postmaster General ${ }^{25}$.

In the first-mentioned list headed Forces for operations in North West Cape. Forces (for Rebellion). Local Forces, establishments, districts, names of commanders and bases appear.

The following are examples:

\begin{tabular}{clll} 
Establishment & \multicolumn{1}{c}{ District } & \multicolumn{1}{c}{ Commander } & \multicolumn{1}{c}{ Base } \\
200 & Carnarvon & Visser/Van Zyl & Carnarvon \\
200 & Britstown & Breedt & Prieska \\
200 & De Aar & Retief & De Aar \\
200 & Victoria West & Scholtz & Victoria West \\
100 & Vryburg & Cullinan & Vryburg \\
200 & Kuruman & Van Zyl & Kuruman
\end{tabular}

The following schedule, dated 24 October, 1914, provides details of the Transvaal Government commandos: 


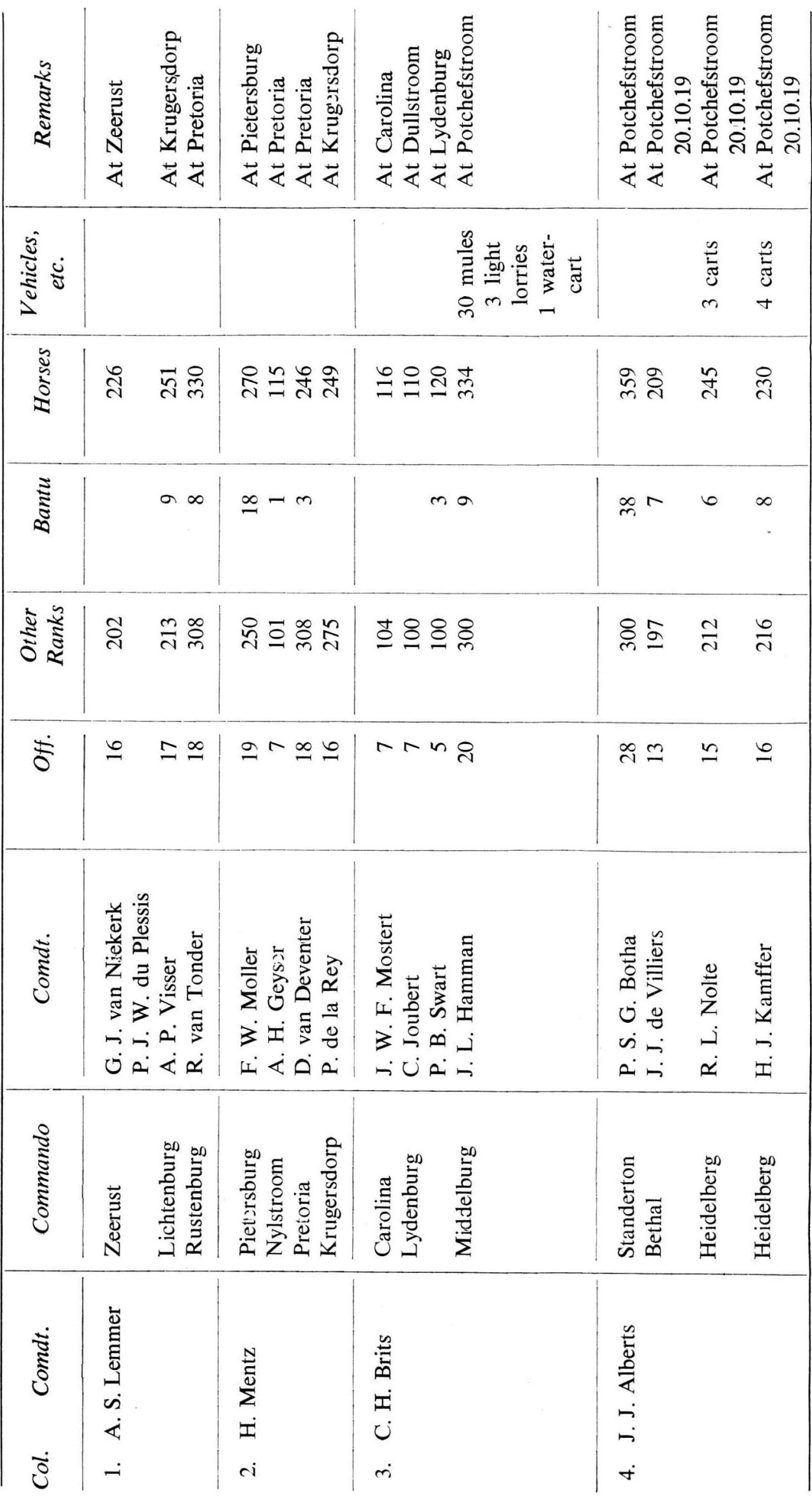




\begin{tabular}{|c|c|c|c|c|}
\hline 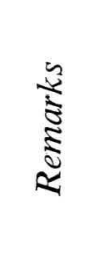 & 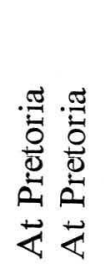 & 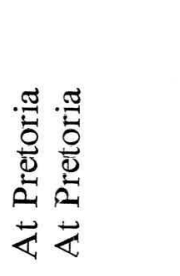 & 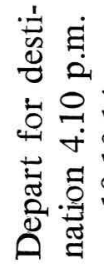 & 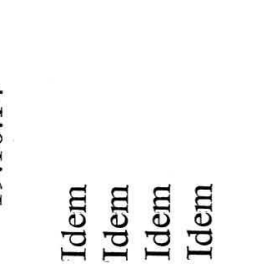 \\
\hline 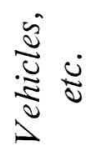 & & & 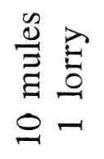 & 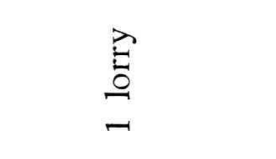 \\
\hline $\begin{array}{c}\grave{\omega} \\
\vdots \\
\vdots \\
\vdots\end{array}$ & đ广d & $\overrightarrow{\widehat{\vartheta}}$ & $\vec{\sim}$ & సู릉ㅇㅇㅇㅇ \\
\hline 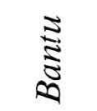 & $\theta^{m}$ & $\stackrel{+}{\sim}$ & - & $\forall \forall$ \\
\hline すั & 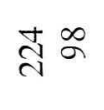 & న্ণ & gे & 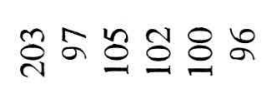 \\
\hline$\dot{t}$ & $\cong r$ & $2 \simeq$ & $\cong$ & $\pm ㅇ ㅢ n n$ \\
\hline ن & 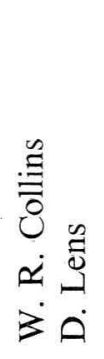 & 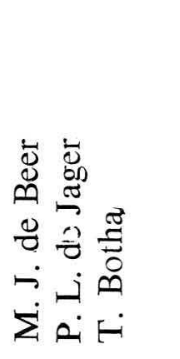 & $\begin{array}{l}\overline{0} \\
\sum^{\circ} \\
\text { मां } \\
0\end{array}$ & 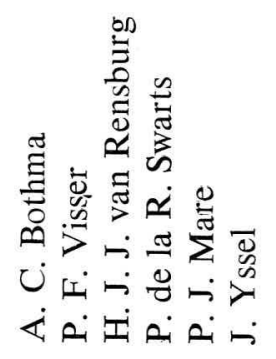 \\
\hline 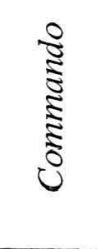 & 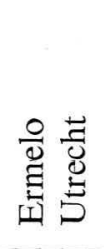 & 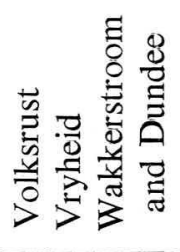 & 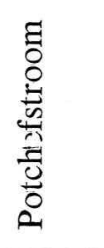 & 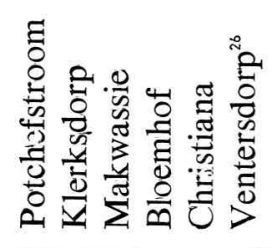 \\
\hline ن & 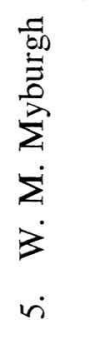 & 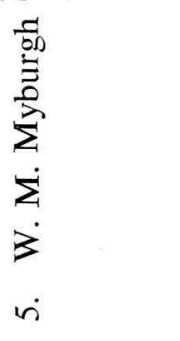 & 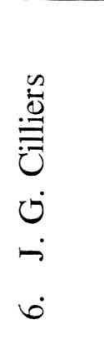 & \\
\hline
\end{tabular}




\section{3}

\section{DURING THE S.W.A. CAMPAIGN}

a. Resumé of the Campaign

Towards the end of 1914 the military position in the Union had been stabilised to such an extent that the military operations in and against South-Weșt Africa could be resumed.

On 1st January, 1915 the position of the Union troops participating in the campaign were as follows:

i. The Northern Force, under Col. P. C. B. Skinner had arrived at Walvis Bay on 25th December, 1914.

ii. The Central Force, under Brigadier General Sir Duncan McKenzie, stood ready in the vicinity of Luideritz.

iii. The Sou'hern Force, under Col. J. L. van Deventer, was assembled near Upington.

Genl. Louis Botha arrived at Swakopmund on 11th February, 1914 and took over command of the Northern Force from Col. P. C. B. Skinner.

The following lines of attack were envisaged:

i. The Northern Force: From Swakopmund to Windhoek.

ii. The Central Force: From Lüderitzbucht through Aus and further east.

iii. The Eastern Force: Under Col. C. A. L. Berrangé, from Kuruman to Keetmanshoop. Base: Kimberley.

iv. The Southern Force: Via Sandfontein to Warmbad and Keetmanshoop.

At the beginning of May, 1915 the Southern part of German South-West Africa was captured almost to the line of Lüderitzbucht, Bethanie, Gibeon and on 12th May Genl. Botha's troops occupied Windhoek.

The campaign was brought to a close on 9th July, 1915 in the northern part of the Territory at Khorab ${ }^{27}$.

b. Functions of the Quartermaster General

It has been said quite rightly that during the Rebellion as well as during the South-West Africa Campaign, the task resting on the shoulders of the Quartermaster General and his section, was particularly onerous.

Innumerable transport problems had to be solved such as maintaining communications between Kuruman and Keetmanshoop. The same applied to provisioning of the troops in German South-West Africa over long distances by land and sea ${ }^{25}$.

The establishment of the Forces on 15th March, 1915 was as follows:

\begin{tabular}{lrrrrr}
\multicolumn{1}{r}{ Force } & Artillcry & Molinted & Infantry & Admin. & Total \\
Northern & 741 & 12773 & 5864 & 1491 & 20869 \\
Central & 575 & 3858 & 5583 & 855 & 10871 \\
Southern & 117 & 8438 & & 631 & 9186 \\
Eastern & 40 & 2016 & & 420 & 2476 \\
\hline Total & 1473 & 27085 & 11477 & 3397 & $43402^{27}$
\end{tabular}

Besides the fact that the transport and provisioning had to be effected over long distances and at specific times in respect of more than 43000 troops with the requisite saddle and draught animals, there was the additional factor of the speed at which the advance was made. In this con- 
nection the following instances can be cited. The First Mounted Brigade covered the distance Auras-Namutoni $(544 \mathrm{~km}$.) in twenty days, at an average speed of well over $27 \mathrm{~km}$. a day. The First Infantry Brigade appeared at Otavifontein four days after the mounted troops. They had attained a daily average speed of $22 \mathrm{~km}$. over a period of sixteen days ${ }^{30}$. Finally, Genl. Botha's troops occupied a territory more or less threequarters the size of the Union of South Africa, within less than six months after departure from the Union.

When these facts are taken into consideration, it becomes clear that the Military Postal Service, the control of which fell under the Quartermaster General's section, certainly faced many difficulties in the field. Archival details in this connection are, however, very limited. The establishment and closure of many Field Post Offices, does nevertheless present some indication of the difficulties encountered.

\section{c. Field and Military Post Offices: Establishment and Closure}

The results of the research undertaken in this regard, is based exclusively on the General Orders that were issued. Research is, however, hampered by the fact that only some of the Field Post Offices were numbered, that the establishment dates of some were not mentioned in the General Orders and that a large number of dates of closure are lacking. The following survey is based on these findings, in chronological sequence, including some data having no direct bsaring on the German South-West Africa Campaign.

12.1.1914 - No. 10 Temporary Field Post Office. Greenpoint Camp, Cape Town was established. Subsidiary to No. 1 Base Post Office, Cape Town.

13.1.1915 - No. 6 Field Post Office. Ramansdrift was opened. It was subsidiary to No. 2 Base Post Office, O'okiep. Closed 31.3.1915. Re-opened 2.4.1915.

No. 10 Field Post Office, Greenpoint Camp, Cape Town, was opened. Subsidiary to No. 1 Base Post Office, Cape Town.

18.1.1915 - No. 11 Field Post Office, Namies was opened. Subsidiary to No. 2 Base Post Office, O'okiep.

No. 12 Field Post Office, Narries was opened. Subsidiary to No. 8 Field Post Office, Kakamas. Closed 10.2.1915. Re-opened 1.3.1915.

19.1.1915 - No. 13 Field Post Office, Swakopmund was opened. Subsidiary to No. 4 Base Post Office, Walvis Bay.

21.1.1915 - No. 14 Field Post Office, Rondebosch was opened. Subsidiary to No. 1 Base Post Office, Cape Town.

28.1.1915 - No. 7 Advanced Base Post Office, Kuruman was opened. No. 15 Advanced Field Base Post Office, subsidiary to Base Post Office No. 1, Wynberg Military Hospital was opened. Hospital, was opened.

10.2.1915 - No. 15 Field Post Office, Schuitdrift, west of Kakamas, was opened. Closed 16.3.1915.

No. 4 Field Post Office, Bloemfontein, Headquarters, was closed. 
12.2.1915 - No. 18 Field Post Office, Burgher Camp, Wynberg, was opened.

23.2.1915 - Field Post Office, Garub, east of Tschaukaib, was opened. Subsidiary to Lüderitzbucht.

26.2.1915 - Field Post Office, Nonidas, was opened. Subsidiary to Walvis Bay.

28.2.1915 - No. 8 Field Post Office, Kakamas, was temporarily closed. Subsidiary to Headquarters.

1.3.1915 - No. 12 Field Post Office, Narries, was re-opened. No. 8 Field Post Office, Kakamas, was temporarily closed at the time of the re-opening of No. 12 Field Post Office, Narries.

7.3.1915 - Field Post Office, Boesmanspruit, about $192 \mathrm{~km}$. west of Kuruman, was opened.

14.3.1915 - No. 22 Field Post Office, Husab, was opened on an unspecified date, but prior to No. 23. Subsidiary to Walvis Bay. No. 21 Field Post Office, Goanikontes, Advanced Post from Swakopmund.

14.3.1915 - No. 23 Field Post Office, Kakamas, was opened. No. 23 Field Post Office, Jerusalem. Closed: 30.3.1916.

20.3.1915 - No. 25 Field Post Office, Namib, opened 20.3.1915. Subsidiary to Walvis Bay. Closed 9.4.1915.

27.3.1915 - No. 26 Field Post Office, Nabas, was opened. Closed: 4.4.1915.

30.3.1915 - Field Post Office, Duurdrift, $24 \mathrm{~km}$. west of Jerusalem, opened 30.3.1915.

31.3.1915 - Field Post Office, Njabis, north of Ukamas, was opened.

2.4.1915 - No. 28 Field Post Office, Witdraai, was opened west of Kuruman.

5.4.1915 - Field Post Office, Hudakop, opened forward of Ukamas. Field Post Office, Tschaukaib, was closed.

9.4.1915 - Field Post Office, Tempe, Orange Free State, was closed. No. 25 Field Post Office, Arandis, subsidiary to No. 5 Field Post Office, Walvis Bay, was opened.

10.4.1915 - No. 30 Field Post Office, Kilo 116, subsidiary to Lüderitzbucht, was opened.

No. 31 Field Post Office, Aus, was opened.

No. 32 Field Post Office, Warmbath, was opened.

Field Post Office, Breytenbach's Column, north-west of Ukamas, was opened.

13.4.1915 - Field Post Office, Kalkfontein, was opened.

17.4.1915 - Field Post Office, Seeheim, was opened.

Field Post Office, Kanus, subsidiary to Upington, was opened.

21.4.1915 - Field Post Office, 5 Mounted Brigade, was opened.

Field Post Office, Rooidam, subsidiary to Upington, was opened.

23.4.1915 — Field Post Office, Rossing, subsidiary to Walvis Bay, was opened. 
26.4.1915 - Field Post Office, Jakkalswatır, subsidiary to Walvis Bay, was opened.

8.5.1915 - No. 41 Field Post Office, Karibib, was opened.

14.5.1915 - No. 37 Field Post Office, Kuibis, subsidiary to Lüderitzbucht, was opened. Closed: 4.6.1915. Army Post Office, Windhoek, was opened.

23.5.1915 - Field Post Office, Onquati subsidiary to Walvis Bay, was opened.

25.5.1915 — Field Post Office, Rosebank General Camp, was opened.

31.5.1915 - No. 7 Field Post Office, Kuruman, was closed. Field Post Office, Ebony, subsidiary to Walvis Bay, was opened.

2.6.1915 - No. 38 Field Post Office, McKenzie's Column, Marienthal and northwards, was opened.

Field Post Office, Okahandja, subsidiary to Walvis Bay, was opened.

4.6.1915 - No. 1 Field Post Office, De Aar, was closed.

No. 46 Field Post Office, Trekkoppjies, subsidiary to Walvis Bay, was opened.

8.6.1915 - No. 47 Field Post Office, Usakos, subsidiary to Walvis Bay, was opened.

15.6.1915 - Designations of No. 25 and No. 26 Field Post Offices in terms of announcement amended to Field Post Office First Infantry and Field Post Office Second Infantry.

No. 49 Field Post Office, Seeheim, subsidiary to Kertmanshoop, was opened. Closed: 17.7.1915.

19.6.1915 - No. 51 Field Post Office, Johanalbrechtshöhe, subsidiary to Walvis Bay, was open'zd. Closed: 26.7.1915.

No. 53 Field Post Office, Okasise, subsidiary to Walvis Bay, was opened.

20.6.1915 - Field Post Office, Omaruru, was opened.

23.6.1915 - No. 52 Fie'd Post Ofjice, Wilhelmstal, subsidiary to Walvis Bay, was opened. Closed: 27.6.1915.

27.6.1915 - No. 54 Field Post Office, Keetmanshoop, formerly Base Post Officice but previously closed, was opened.

28.6.1915 - No. 55 Field Post Office, Waldau, subsidiary to Walvis Bay, was opened.

No. 56 Field Post Office, Kalkfield, was opened.

4.7.1915 - No. 57 Field Post Office, Otjiwarongo, subsidiary to Walvis Bay, was opened.

No. 58 Field Post Office, Okaputa, subsidiary to Walvis Bay, was opened.

No. 59 Field Post Office, Otavi, subsidiary to Walvis Bay, was opened.

17.7.1915 — Field Post Office, Rehoboth, was closed.

20.7.1915 - Field Post Office, Kilo 13, was closed ${ }^{31}$.

Further closing dates were not found in the course of this survey, but reference was located in the General Orders of 26th January, 1915 to the opening of the Military Telegraph Offices at Walvis Bay, Swakopmund and Henkries (Northern Force) and Ramansdrift and Marieputs (Southern 
Force). The Military Telegraph Office at Goodhouse was temporarily closed at the same time.

General Orders of 16th March, 1915 publish the fact that the Field Telegraph Office of Jerusalem via Schuitdrift was opened on 10th March, 1915. It was also officially announced on 12th October, 1915 that as from 1st October, 1915 the Unit's Headquarters (Cape Town) would for a while remain in operation to finalise current matters. At the same time it was announced that Maj. Sturman would in future assist the South African Gifts and Comforts Fund in connection with the Expeditionary Forces (Europe and elsewhere), and would for this purpose, retain his military rank.

On 1st August, 1915 the Director of Posts and Telegraphs, falling under the Administrator of the Protectorate of South-West Africa, commenced his activities in the territory. At the sam!s time there were still seventeen operative post offices manned by the military personnel. Ex-servicemen of the Corps were recruited and South-West Africa obtained her present Department of Posts and Telegraphs in this unique way, its foundations having been laid by the South African Post and Telegraphs Corps during and shortly after the Campaign.

On the 31st December, 1915 sixty-four civilian post and telegraph offices and two private bags were in use $\mathrm{s}^{32}$.

\section{d. The Handling of Post}

In the first circular issued by the Director of the Army Postal Service, Maj. Sturman, in Cape Town on 30th September, 1914, it was stipulated, inter alia, that the Officer Commanding No. 1 Base Post Office, Cape Town was to be responsible for the organisation of the above-mentioned office.

The Officer Commanding of an Advanced Base Post Office was, inter alia, responsible for the dispatch of locked mail-bags to the Field Post Offices and the Base. At the same time, he had to arrange for the sorting and distribution of incoming and outgoing mail and for obtaining all unit changes of address and forwarding these to the Director.

Arrangements had to be made directly with the Quartermaster General's representative in a Base regarding transport for the distribution of mail to the Columns.

The N.C.O. in charge of a Field Post Office or on duty with a Column was responsible for the receipt and distribution of the mail to the troops served by his office. This N.C.O. was also expected to dispatch outgoing mail to the Base. At the same time he was entrusted with the sale of stamps and postal orders, the registering of letters and other post office operations.

\section{e. Correspondence}

Correspondence of serving members of the Forces to relatives and friends could be conducted:

i. By means of printed post cards.

ii. By means of ordinary post cards.

iii. By means of registered and/or unregistered letters.

In the case of urgent letters, it was laid down that these had to be submitted to the Officer Commanding or the officer concerned under whose command the sender was serving. After approval of its contents, such a 
letter had to be placed in a special envelope in the presence of the Officer Commanding or officer concerned, who then appended his signature thereto without any mention of his rank or unit.

In the case of other envelopes, the letters were subject to military censorship and members of the Forces were accordingly advised to use printed postcards. Postcards and letters from members of the Forces on active service to members of their families, etc., could be sent unstamped, but in this regard it was recommended that the envelopes be left open for censorship purposes. Registered postal articles had to be paid for in advance, whilst all the mail sent to the troops was subject to stamp duty at ruling rates.

\section{f. Postage Stamp Problems}

Before the abovementioned Circular was issued, the Postmaster General, Department of Posts and Telegraphs, had to contend with the problem of postage stamps and franking. On 4th September, 1914 he reported to the Secretary of Defence that the Controller, Posts, in Cape Town had received a large number of unstamped mail articles from troops in the field with overseas destinations.

In the same letter the attention of the Secretary of Defence was drawn to the International Postal Union's directive that postage had to be prepaid. Notices to this effect, the Postmaster General continues, were sent to the Officers Commanding the A, B, C, and D Forces. Unstamped letters already posted, would be sent to the addressees but the receivers would have to make good the cost.

On the 2nd October, 1914 it was announced in the Army Post Office Orders that the Treasury had decided that all unstamped or insufficiently stamped mail, addressed to troops in the field, would be subject to penalty stamps being affixed, in accordance with the existing regulations and that the receiver would pay the fine. In this connection the Advanced Base Post Offices and Field Post Offices were instructed to keep an adequate reserve of penalty stamps.

Shortly afterwards the Quartermaster General announced the following with regard to the postage due on postal articles from relatives and friends of members of the Union Defence Force on active service :

i. All postal articles destined for the troops had to be fully stamped.

ii. Parcels with a weight of up to eleven pounds could be sent from any civilian post office in the Union to troops in the field at the ruling postal rates.

iii. No postage was payable on letters and postcards sent by troops in the field to family and friends in the Union if these were handed in at Army Post Offices.

iv. With regard to parcels coming from the troops, the postage had to be prepaid ${ }^{33}$.

The arrangement whereby the public had to affix stamps to letters sent to members of the Union Defence Force on active service did not always meet with approval. The surveyor, Gustav Baumann of Bloemfontein whose two sons joined respectively the Transvaal Horse Artillery and President Brand's Rifles as volunteers, wrote to Genl. J. C. Smuts about this on 2nd November, 1914 and, inter alia, raised the following objections: 
It does seem absurd that when a man is serving his country, the country should demand that those who are writing to him or sending him literature should have to pay towards the revenue, whereas when he either by mishap or otherwise should cease serving his country, the government is prepared to waive the revenue.

On 7th November, 1914 Maj. Sturman telegraphed the Quartermaster General that troops in the field still did not affix stamps to letters destined for abroad. Notwithstanding the fact stamp purchasing facilities were provided. As a result of this complaint confirmation appeared in Unit Orders of 11 November, 1914 to the effect that only mail destined for the Union could be sent without postage stamps.

On the same day Cmdt. A. S. D. Erasmus of the Pietersburg Commando complained that letters sent there by members of the Union Defence Force who were on active service and which were stamped were surcharged twice the value of the actual postage owing.

Soon afterwards on 17th November, 1914, it was made known in Defence Force Orders that all letters to troops were subject to postage at the ruling rate. Parcels for troops in the field were to be despatched at inland postage rate and the requisite stamps had to be affixed to such parcels sent by this troops.

From a reply by the Quartermaster General to an enquiry from Burghersdorp on 23rd November, 1914, it appears that troops who posted letters had to mark their postal articles "on active service" in order to ensure dispatch free of charge ${ }^{34}$.

In spite of these concessions the Johannesburg City Council recommended that all letters, newspapers and parcels addressed to soldiers on active service should be transported free of charge.

The City Council passed this motion on 24th November, 1914, giving as its motivation the circumstances in which dependants found themselves and the fact that insufficiently stamped postal articles were being returned to the senders. The Quartermaster General had no alternative but to reject this and later representations ${ }^{35}$.

Shortly before the City Council's request was brought to the attention of the military authorities, all Officers Commanding in the field, namely in the Transvaal, the Orange Free State, at Calvinia and at Upington, were informed that to ensurs free postage, letters from members of the Union Defence Force on active service had to be clearly endorsed "on active service." All letters sent to these troops in the Transvaal and Orange Free State had to be addressed to the Army Post Office, Johannesburg ${ }^{36}$.

In a Defence Force Order of 8th December, 1914, emphasis was once again laid on postage stamps. On 19th February, 1915 in an order to the Army Post Office and on 23rd February in a Defence Force Order, it was decreed that all correspondence from troops in the fild bearing the endorsement "Op Aktiewe Dienst" or "I.Z.M.D." (Dutch: In Zijn Majesteits Dienst) or "On Active Srrvice" or "O.H.M.S." were entitled to postage free conveyance to the Union, Rhodesia and the Protectorates.

The last General Order relating to the postage-free despatch of letters was issued on 25th August, 1915, and it stated in reference to the Military Protectorate (South-West Africa) that : 
i. Private letters and postcards sent by members of the Union Defence Force (U.D.F.) who are still on active service, are still accepted for cost-free dispatch provided that "on active service" and the surname, rank and unit of the sender appear on the lower left hand corner of the envelope or on the address side of the postcard.

ii. Thr above-mentioned concession lapsed on 1st September, 1915 in respect of units of the U.D.F. which had been disbanded ${ }^{37}$.

g. Envelopes, Writing Materials, Postcards

Very few particulars relating to the above items are obtainable from the available archivalia. It has been established, however, that the Secretary of Defence directed a request to this Acting Postmaster General on 31st August, 1914 to obtain 250000 postcards for the troops in the field and that cards were printed by the Government Printer and delivered to the Department of Defence on 10th September, 1914.

A Defince Force Order dating back to 27th October, 1914 mentions the fact that due to non-compliance with Field Post instructions the acceptance of letters would be temporarily suspended and only for the use of postcards by troops would be allowed. The following extract is of interest:

The greatest possible use is to be made of postcards but letters can be despatched if private matters of an important nature are dealt with. Such letters are to be signed by the officer commanding as proof that he has read through these and that the instructions are being complied with.

All ranks are warned that it is pointless to attempt sending letters through unauthorised channels.

The order that troops were limited to the use of postcards, was later withdrawn on 28th October, 1914 without a reason being given for this step.

On 29th November, 1914 the Military Stationery Dupot at Pretoria telegraphed the Department of Defence concerning the printing and distribution of postcards, saying that on 23rd October, 191450000 postcards ("On Active Service") had been ordered but up to 9th November, 1914 only 14000 had been received. On 2 nd December of the same year the Quartermaster General received an instruction to send 10000 postcards to Prieska. At the same time it was reported that small quantities had been sent out to all Military Post Offices and that 250000 were still on order from the Government Printer, Cape Town. Shortly after receiving the request from Pretoria, the Quartermaster General forwarded 5340 postcards to Cape Town, i.e. his total stock at that time. This information gives some indication of the quantities supplied to the troops. On 19th February, 1915, it was announced that arrangements had been made with the S.A. Garrison Institutes, to make envelopes and writing materials available at Military Post Offices against a small charge. On 3rd March, 1915, the Military Post Office staff was once again notified that Active Service Postcards were available, free of charge, on request at Base and Field Post Offices.

h. Addressing of Correspondence

The oldest official announcement by order of the Quartermaster General, regarding the addressing of correspondenc's to members of the U.D.F., 
in this instance with particular reference to members doing commando service in the Transvaal, dates back to 28th October, 1914.

All letters and telegrams had to be addressed according to the following example: S. P. Jooste, Commandant Collins, Commando Army Post Office, Pretoria, i.e. the addresses had to contain the initial(s), surname, unit, the post office concerned and the place where such office was situated. (N.B. This related to Commando members who had not been allotted Force numbers at this stage).

Addresses on letters and telegrams to soldiers in training camps or soldiers performing garrison duties had to contain the name of the unit or commando of which the addressee was a member and the location concerned.

In his circular of 28th October, 1914, the Quartermaster General requested newspaper editors to publish the fact that correspondence destined for members of the Union Defence Force serving in the Transvaal, should be addressed to the Army Post Office, Johannesburg and not to the Army Post Office, Pretoria.

On 3rd November, 1914 the notice of 28th October, 1914, as amended, was published in Defence Force Orders and on 5th November, 1914, it was indicated in Army Post Office Orders, that difficulties were being experienced by the Base Post Office as a result of incomplete addresses. Officers Commanding Field Base Post Offices and Field Post Offices were instructzd to point that out to the addressees.

In the orders of 2nd December, 1914, members of the Forces leaving their units or being discharged or transferred, were instructed to leave their forwarding addresses at the orderly rooms of their respective units. The fact that the military postal service could not become involved in tracing military personnel was also mentioned in this Order.

On 3rd December, 1914, Major Sturman informed the Quartermaster General that in regard to complaints concerning delayed deliveries or non-deliveries of mail, it should be noted that despite repeated announcements made in Defence Force Orders, by civilian Post Offices and in the press to the effect that all letters should indicate the relative number, rank and name of regiment, battery or unit, a large quantity of postal articles which did not comply with these requirements was lying in Cape Town. Major Sturman gave the following examples of such insufficiently addressed postal articles:

i. M. J. Sowen Esq., Caterer to Troops on Active Service, Cape Town.

ii. M. van der Weel, Army Base P.O., Cape Town.

iii. Private A. Coombs, Reg. No. 7924, Genl. Botha's Army, West Africa.

According to a report by Maj. Sturman, 3567 letters and other postal articles, addressed to troops to whom they could not be delivered due to inadequate addresses, were received in November, 1914.

Maj. Sturman in fact offered to request Reuter's News Agency to warn the public and to request the aid of the Postmaster General and all postmasters. In a Force Order of 15th December, 1914, it was again pointed out that large quantities of inadequately addressed letters and parcels 
of the Armed Forces who had not yet done so, were to inform their relatives and friends that all addresses must include the regimenal number, rank, name of the company, squadron, platoon number in the battalion, regiment or command in which the addressee was serving.

On the 7th January, 1915, the Director of Military Postal Services proposed to the Quartermaster General that in view of the fact that the Southern Force was spread out over so vast an area and that this whole area was being served by various postal routes, the designations Northern, Central and Southern (formerly A, B, C, and D) Forces were unnecessary when addressing official letters.

Where, up to that time, it had been customary to use the following address, viz, Staff Officer for Signalling, "B" or "Southern Force," the following address was now suggested: viz, Staff Officer for Signalling, Upington.

In a similar vein Maj. Sturman furthermore stressed the desirability of omitting the specific Force in which the member was serving, when the name of the regiment and, in some instances, the battalion was given.

These suggestions were apparently not implemented. Army Post Office Orders of 8th February, 1915, are interesting for the statement that -

In a large percentage of cases the addresses given by the senders are not complete, but to return such articles to the senders would give rise to a want of confidence in the resourcefulness, capacity and efficiency of the Corps.

In Defence Force Orders of 30th March, 1915, it was announced that letters mailed to mimbers of the Eastern Force, were to be addressed as follows: Eastern Force, Army Post Office, Base 7, Kuruman.

Adverting once more to the subject of addresses on letters or parcels, etc., Defence Force Orders dated 27th April, 1915, again announced that large quantities of inadequately addressed postal parcels were still being received ${ }^{33}$. This impeded the location of the addressees and retarded delivery. The attention of the troops was again drawn to the correct procedures. Whether these repeated reminders produced the desired results is not evident from available archival sources.

i. Delivery of Mail

One of the reasons for the delay in delivery of mail to the troops serving in the Transvaal, the Orange Free State, German South-West Africa and elsewhere, was as already stated, the tendency of senders to address their mail inadequately.

Another problem with which the Military Postal Service had to contend was that of not being timeously and fully informed about the whereabouts of units stationed in the field.

A list of the units on active service had been sent to the Director of the Military Postal Service by the Quartermaster General on the 30th September, 1914, with the promise that a list of officers and men on brigade trains, field ambulances, supply and transport services, etc., and the forces to which they were attached, was to follow later.

This system obviously did not function satisfactorily because various units and commandos frequently moved from one place to another, particularly during the Rebellion. 
The Quartermaster General was, for instance, requested on 23rd October, 1914, to furnish the delivery addresses of Naude's Scouts, the Brixtown Commando, the Rhodesian Rifles, the Tembuland Horse, Loxton's Scouts (De la Rey's Rifles), the Standerton Commando, the Irish Light Horse, the Bloemhof Commando and other units in the field, as Maj. Sturman and his staff had no addresses for these units.

A search was also being made for the addresses of certain other units such as 2 Field Ambulance, which at that time had not been commandeered for active service. In other instances the locations of specific units were unknown.

On 29th October, 1914, the Quartermaster General replied to the abovementioned requests with a promise to send out such a list, even though it had been reported that certain units had not yet been mobilised.

A list of the names of the commandos serving in the North Western Cape and the Transvaal, for the use of the Military Postal Service, was sent to the Postmaster General on 30th October, 1914, with the promise that similar lists would be forwarded to him the moment they became available.

This system gave rise to various problems: In some cases the information furnished was incomplete and in other instances it was found that the locations of units were being changed almost daily.

On 23rd Novembər, 1914, it was announced that the Commanders had been authorised by the Quartermaster General to send information regarding their future movements to the Military Postal Service from the nearest telegraph office. To obviate leakage of possibly important military information, it was stipulated that officers commanding were to be very circumspect in their telegrammes.

The problems the Military Postal Services had to contend with at the time of the Rebellion are obvious from a report sen $i$ to the Quartermaster General, by Major Sturman, on 4th December, 1914.

In his introduction Major Sturman states that up to the outbreak of the Rebellion, the activities of his Corps had been fairly straightforward. At the time when thousands of burghers were being mobilised and attached to various units, the names of some of which were unknown, and they started moving in all directions, the only way to solve the problem had been to station fully equipped postal coaches to railway stations. There they served as Field Post Offices. When the commandos arrived at the stations, mail was issued to them and information gained from officers regarding the destinations of the commandos. This information was then coded and sent to the various Army Post Offices. Maj. Sturman only received the official names of the commandos at a later stage. At approximately the same time another problem arose. Names of commandos were being changed without official consent. In this way the name of the Prieska Commando was changed to Parkinson's Horse, whilst the Barkley West Commando, under the command of L. B. O'Donovan, was officially unknown. This "Commando" was at Danielskuil on 28th November, 1914, but at Kuruman four days later. The Ca'vina Commando became known as the Noord-Bokveld Commando. Furthermore, there were commandos that were sub-divided into three sections, e.g. the Piet Retief Commando, with one section, commanded by Col. Myburgh at Upington and another section, commanded by Col. Mentz at Premier 
Mine. The Potchefstroom Commando can be quoted as a similar example, with one section under Bothmer at Boshof, one under Buitendach at Klerksdorp, one under Dreyer at Bethlehem and one section under Grobler at Kroonstad ${ }^{39}$.

Major Sturman added that if, in the case of the last two instances quoted, all the mail had been forwarded to one of the commandants, they would not have known where any of the other sections were. Some delay was caused by the fact that the base at Upington had been cut off for a period of approximately two weeks. The public, according to the report, blamed the Military Postal Services, not realising that the headquarters of this organisation was unaware of the fact that the Rand Light Infantry was stationed mainly at Lüderitzbucht but that two companies were waiting at De Aar. Maj. Sturman thought that after the Rebellion things would probably improve but that one would still have to contend with the irregular mail-boat connections with German South-West Africa.

In the same month, i.e. on 25th November, 1914, the "Natal Mercury" made mention of the complaints received by the editorial staff about the delivery of mail to the troops. Maj. Sturman forwarded this news report to the Quartermaster General and stated that explanations could be offered for some of the complaints. In some cases the circumstances of war were not being considered, whilst in other cases mitigating circumstances, such as letters being inadequately addressed, rapid movement of troops, sub-division of commandos and the fact that information of this nature and information concerning the destination of units and commandos were lacking, were the root of the problem.

Under the heading, "Parcels for our Soldiers," the "Rand Daily Mail" of 8th December, 1914, published a complaint about the delivery of mail and parcels. On 22nd December, 1914, the attention of the Quartermaster General was drawn by Maj. Sturman to the fact that the difficulties in delivery of mail in South-West Africa were caused by the old quadripartite division of the forces, whereas in fact only the Northern, the Central and the Southern Forces existed.

On 30th December, 1914, Maj. Siurman addressed a plea to the Quartermaster General requesting that definite names be established for commandos prior to their service in the field, that standard addresses and envelopes be designed and that lists of names of members of the various commandos be given to him. Later, after his return from a number of commandos, Maj. Sturman declared that his organisation was indeed functioning more effectively. At the same time, however, he requested that the district, the town of mobilisation, the composition and the rallying points of commandos be communicated to him. He also suggested that instructions be issued to each commandant of a commando to select a mail orderly who knew the members and who could be held responsible for the delivery of the mail in such commando.

According to Maj. Sturman the movement of field post offices, by military comanders was never done without his knowledge. The co-operation between himself and these commanders remained excellent at all times.

It is not known whether there ever was any reaction to the foregoing suggestions of Maj. Sturman, but one thing is clear, complaints about the delivery of mail continued. 
A few causes for this unsatisfactory state of affairs mav be deduced from the report by the Postmaster at Premier Mine for the period 14th December, 1914-15th January, 1915. He reported that letters addressed to certain Active Citizen Forcs Units were delivered regularly by virtue of the systematic arrangements made by unit commanders to collect mail and where necessary ensure that full addresses were used.

At the commandos he found, in contrast to the abovementioned regiments, a lack of systematic appointment of mail orderlies who could collect mail at the nearest Post Offices. Where this was in fact done, the orderlies often failed to distribute the mail.

Furthermore, it was found that many letters to commandos were wrongly addressed, some of them to units with names which were in fact not recognised officially. In this connection reference was made by the Postmaster to the commando of Col. Dirk van Deventer. Among the members of that commando there were 150 who came from Premier Mine. During their peregrinations, these members called themselves The Cullinan's Horse.

Instances such as Col. Cmdt. Geyser's commando at Nylstroom which refused to deliver mail, and Col. van Deventer, who, after refusing to accept any mail, left for Heilbron, made matters even worse.

Other commandos, according to the Postmaster, were guilty of similar irregularities.

A part of Cmdt. de Beer's commando joined up with the rebels under Gen. J. C. G. Kemp after writing letters applying for compassionate leave on the grounds of illness at home. This immediately weakened the commando concerned. To prevent further thinning out of the ranks in this case, the granting of leave was refused.

At Roberts Heights, according to the Postmaster when later recalling from memory, officers commanding commandos, did not want to be bothered with letters. Accordingly mail was never handed over to addressees and was left lying about.

In a report received from the Postmaster at Warmbad (Transvaal), it was stated that postal deliveries to the commandos had failed and that the mail was piling up. In other monthly reports to Maj. Sturman, it was reported that hundreds of letters addressed to the Bethlehem commando members, wer' found at the station and that many of them had been opened. The postal authorities at De Aar had failed to get into contact with this commando although it was reputedly in that area.

As a result of earlier complaints, the Department of the Assistant Quartermaster General submitted a suggestion to the Quartermaster General to allocate specific names to commandos, to obtain lists of namıs of commandos, to inform every member of the commandos of his correct address for advice to his next-of-kin, etc., and to send a few members of the Defence Force to the commandos to rectify the unsatisfactory position. On the 7th January, 1914, definite names for the commandos were approved and further arrangements made in this connection. Full details in this regard and relative to the first three brigades were furnished to Maj. Sturman.

On 16th January, 1915, Capt. H. Frew reported to Major Sturman from No. 1 Base Post Office, Cape Town that, after receiving the mail at his 
office and checking everything, he always informed the units concerned by telephone that the mail was available for delivery. After that the mail-bags were taken to the orderly rooms where the mail was distributed. Regarding the delivery of mail to Lüderitzbucht, Capt. Frew reported that during the period 7 to 28 December, 1914, no ships sailed from Cape Town to Lüderitzbucht and that previously the same position had applied between 29th September and 19th October and again between 3rd and 14th November, 1914.

At the time there was no alternative means of ensuring a regular delivery of mail to Luideritzbucht during the periods in question.

The state of affairs concerning the delivery of mail at Kakamas about the beginning of February, 1915, can be deduced from the correspondence of Maj. Sturman, dated 3rd February, 1915 to the Assistant Quartermaster General.

He stated, inter alia, that in view of the fact that operations were spread out over a vast area, the situation initially presented problems. Small groups of burghers went to the forward posts, a distance of about sixty miles from Kakamas. Orderlies were infrequently sent to the Field Post Office. Afterwards an Advanced Post Office was opened at Narries, but, as a result of enemy attacks, it had to be moved again. The local regional commander still had not granted permission for the re-opening of that Field Post Office.

In the meantime everything was being done to afford postal facilities to the troops stationed between O'okiep and Kakamas and to this end Field Post Offices were later opened at Ramansdrift, Namies and Narries to form a link between the earlier A and B Forces, which were now known as the Southern Force.

An added problem was that the Railways and the Gifts- and Comforts Fund, which were not part of the Military Postal Service, also conveyed parcels. A number of these, which were incompletely addressed, landed up at the wrong destinations.

From these particulars it is obvious that, as far as the delivery of mail was concerned, serious problems were being experienced. Maj. Sturman's awareness of a number of such problems is further evident from an extract from the Corps Orders, dated 6th February, 1915, which read as follows:

The success or otherwise of the work of the South African Postal Corps depends upon the degree in which the Corps is successful in bringing to the hands of intended recipients, articles of mail which have been consigned to the Army Post Office for delivery.

In the Defence Force Orders of February 9th, 1915, it was again stressed that officers commanding units were to appoint postal orderlies who could fetch mail from either the Field or Base Post Offices. They were to be supplied with lists of names of members of detached sections, patrols, etc., and they had to be reliable. Letters and any other undelivered mail had to be returned to the abovementioned post offices within seven days of receipt. Where possible, the mail had to be returned, correctly readdressed. 
In spite of this instruction, the delivery of mail still did not always come up to expectations. On 10th February Capt. O. L. M. van der Merwe, of the Murraysburg Commando, wrote a letter from a forward camp where he was stationed, to the Minister of Defence, stating that he and his fellow burghers had left their homes almost four months previously and that they were anxious to receive news from their families. Letters to them which had been posted at Murraysburg on 19th January, 1915, only reached them on February $9 \mathrm{th}^{40}$. To this letter Maj. Sturman replied that seeing the enemy was in the vicinity, the transport of mail from Upington to Kakamas had been delayed initially. After that, the railway line between Prieska and Upington had been washed away and further delays were experienced. At the time of Maj. Sturman's reply the Murraysburg Commando was stationed at Narries and mail had to be transported from Upington, a distance of more than $160 \mathrm{~km}$.; over poor and sandy routes.

On 16th February, 1915,the Defence Force Order of February 9th, 1915, was augmented:

i. Firstly it fixed responsibility for the distribution of papers, letters and parcels addressed to a unit as being transferred from Army Post Office to unit control immediately mail was handed to the Unit mail orderly.

ii. The mail orderly was required to sign a receipt for every letter or parcel handed to him at the Military Post Office. In turn each addressee was required to acknowledg: receipt of his mail in writing.

iii. All items of mail, destined for addressees who are not with their units were to be re-addressed to their last known addressış.

iv. In the event of the address being unknown, such mail was to be sent to the Army Post Office with an endorsement to the effect that the whereabouts of the addressee was unknown. Such endorsement was to be signed by the endorser ${ }^{41}$.

v. In the event of the decease of an addressee, mail addressed to him was to be endorsed accordingly and each endorsement signed by an officer. In these cases the utmost care was to $b z$ exercised to verify the actual death.

vi. All newly addressed or endorsed articles of mail were to be handed in at the nearest Post Office. A receipt for the return of all registered letters or parcels had also to be obtained.

vii. Mail orderlies were furthermore held responsible for the immediate return of all mail-bags to the Field Post Office ${ }^{42}$.

\section{j. Parcel Post}

As far as parcels are concerned the following pertinent details have been verified.

On 23rd November, 1914, it was announced that after uniforms had been issued to burghers, their civilian clothing could be sent home and that one parcel would be allowed per person. These parcels, marked with the surname, rank and commando of the consignor, were to be forwarded to the Army Post Office at Johannesburg, Bloemfontein, De Aar or Cape Town. There they would be franked and delivered to the home addresses concerned. 
In the Corps Orders of December 9th, 1914, it was stated that parcels addressed to troops were not reaching their destinations. In some cases such parcels were not handed in at an Army Post Office but forwarded to the officer commanding the Gifts and Benefits Section. In other instances, the parcels were too large and had to be sent by rail. According to these Corps Orders, only parcels handed in at any civil Post Office in the Union and in regard to which the postal charges had been pre-paid, would be despatched in the same way as letters.

On 8th February, 1915, it was, inter alia, announced in Corps Orders that undelivered parcels addressed to troops in the field, would be returned free of charge and that it was forbidden to send butter, eggs and fish.

With regard to gift parcels to the troops in German South West Africa, the following military arrangements were made in Cape Town:

i. Every day a wagon would be sent to the station to take receipt of all goods arriving by passenger train and destined for delivery to the troops.

ii. These goods would be off-loaded at a shed in the harbour area.

iii. Lists rugarding the dates of arrival an despatch and the names of consignors would be compiled, as well as one list of the consignee units.

iv. Donors would be given a receipt, but in many instances details in this connection were lacking.

v. Parcels for the C Force would be placed together and were addressed initially to The Ordnance Office, Lüderitzbucht, but at the request of this officer, the address was changed to that of the Chief Magistrate after 28th February, 1914.

vi. A list of details was to accompany the consignment in which every parcel was to be marked CM/L i.e. "Chief Magistrate, Lüderitzbucht." Goods despatched to Port Nolloth, were marked OO/PN i.e. "Ordnance Officer, Port Nolloth." Gift parcels for the Force operating near Prieska were handed to the local Ordnance Officer while parcels for soldiers near Cape Town, were assigned to the Sergeant Quartermaster.

In a report of the 10th December, 1915, by Lt. H. E. Duigan, who was in command of the Gift Parcel Organisation in Cape Town, he stated that parcels were not accumulating and that ships for Lüderitzbucht and Port Nolloth had sailed from Table Bay on 7th and 9th December respectively.

In the Defence Force Orders, dated 10th December, 1914, mention was made of complaints that had been received by Defence Headquarters about goods for the troops in the field being stolen out of gift boxes and that those responsible would be punished.

Theft was not the only reason for parcels not reaching their destinations. Ineffectual packing, as a result of which the contents of parcels became scattered, encouraged theft, while in other instances, parcels to addressees who were working in the harbour area, were accepted on their behalf by friends. In a letter to Major James A. Vennings ${ }^{43}$, dated 28th January, 1915, the Deputy Director of the Military Postal Service informed him of the fact that half the fruit sent to troops arrived at its 
destination rotten and that in future only dried fruit should be despatched. In reply to this letter, the Deputy Quartermaster General stated on the 29th January, 1915, that theft had to cease and that if no solution could be found, consignors and consignees would persist in complaining. From this correspondence it is also evident that the distribution of parcels was in fact not part of the duties of the Military Postal Service and that Major Sturman was under the impression that in this regard:

i. the existing organisation was not really designed for handling of parcels;

ii. the Army Post Office was nevertheless in the unfortunate position of being held responsible by the public for the correct delivery of parcels;

iii. it was desirable that the existing instructions, regarding the acceptance of free amenities and gifts for the troops, be revised.

From 17th July, 1915, the Gift Section of the Army Post Office was closed, but parcels were still accepted on behalf of the South African Mounted Rifles (S.A.M.R.) who were to form the occupation force in South-West Africa. Parcels for the S.A.M.R. could bı sent to the Army Post Office in Cape Town and not to the Gifts Section.

\section{k. Censorship}

As early as 23rd September, 1915, the Quartermaster General informed the Director of Postal Services that censors in the field should be warned not to permit the passage of information regarding the naiure of the military operations in German South-West Africa, that the reports of Reuter's correspondent should be carefully censored in the field and that a special code was to be used by the Director for secret instructions to censors in the field.

These measures were taken to prevent any information of military importance from reaching the enemy, as news from New York, the Netherlands and Germany was being received in Windhoek within eighteen hours after being despatched.

On 28th September, 1915, Maj. Sturman replied that the censors in the field had been informed and that steps were being taken regarding the secret code.

This directive was followed by Army Post Office Circular No. 1 of 30th September, 1914, in which instructions were issued regarding censorship in the field. The circular was directed to officers commanding advanced base post offices who were to act in accordance with the Quartermaster General's instructions on censorship in the field. It was stressed in the circular that special attention should be given to all censors in the field to outgoing mail before despatch. With the exception of official telegrams, the same applied to Military Telegraph Offices.

In cases where mail was to be sent to Cape Town and the censor had not yet completed his task, the uncensored postal articles had to be sent in specially marked bundles to avoid delay. It was further specified that mail in transit should in no circumstances be intercepted by columns without reference and explanations to Base Post Office Headquarters.

Such a case was reported to the Secretary of Defence by the Acting Postmaster General on 16th October, 1914. Two mail bags which arrived in Table Bay from Lüdıritzbucht on board the steamer Gaika on the 11th 
October, 1914, were opened by Col. Price on instructions from Gen. J. C. Smuts. Gen. Smuts was expecting an important message from Col. Geo. Farrar and instructed that the mail bags be opened on board ship. The Acting Postmaster General requested that Col. Price be informed of the irregularity.

This incident occurred six days before the Quartermaster General decided to approve of the next supplimentary draft instructions recommended by Maj. Sturman regarding censorship in the field. These instructions concerned all mail and telegrams handed in at civilian post offices within the operational areas of the A and B. Forces. It was directed that people trying to evade censorship in the field by using civilian post offices, should be subjected to the relative regulations to prevent the possibility of military information reaching the public through this channel. It was also suggested that steamers using the sea routes of $\mathrm{C}$ and $\mathrm{D}$ forces be subjected to strict censorship. Letters posted on ships that used west coast ports and letters posted in the Cape Town harbour area, had to be dealt with in the same way.

On the 5th November, 1914, it was announced in Corps Orders that the letters of officers would not be opened by censors in the field, but had to sent under special cover to the chief censor in Cape Town.

On the 7th January, 1915, the Army Post Office and censorship in the field was separated. On 19th February, 1915, it was announced that the Minister of Defence had ordered all force commanders to ensure that telegram $\mathrm{s}^{44}$ from the battle area should under no circumstances contain information about men killed, wounded or missing.

\section{Conclusion}

As mentioned at the beginning of this survey, the South African Field Post Service, as in the case of the Telegraphy Section, closed its offices on 1st October, 1915. The Director of the Field Postal Service, also known as the Army Postal Service and his staff were henceforth directed to assist the South African Committee regarding the organisation and provision of gifts to members of the military expeditionary forces. They however retained their military ranks.

Already after 31st July, 1915, all the members of the Corps serving in the Proteciorate were renumerated by the Postmaster General.

On the same date the Corps officially ceased to exist. Ex-members desiring a similar military employment, were given the opportunity of re-attesting for the duration of the War including a period of six months thereafter.

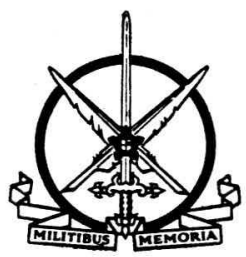




\section{SUMMARY}

The civilian postal organisation steadily developed in South Africa in the second half of the 18th century with the opening of the first post office in Cape Town.

Towards the end of the 19th century the British colonies in South Africa as well as the two Boer Republics had well organized postal and telegraphic networks.

During the Anglo-Boer War both the Republics and the British military organisations maintained their respective field postal organisations.

On the establishment of the Union (1910) the Department of Posts and Telegraphs took over the functions of the pre-Union civilian postal organisations. Legislation followed in 1911.

On the 30th September, 1914, the South African Field Post and Telegraph Corps comprising a signals and a postal section, was established with a personnel of 500 men. The corps functioned until 30th September, 1915.

The Corps fell under the control of the Quartermaster General and functioned during the first part of the South-West Africa campaign, the Rebellion and, thereafter, in the actual campaign against and in South-West Africa, after which it was disbanded.

Ex-members of the Corps laid the foundations of the present post and telegraph organisation in the protectorate of South-West Africa.

From an organisational point of view, the Army Postal Service functioned smoothly until the Rebellion. The rapid movement of commandos then for a while impeded the delivery of postal articles. Additional problems such as faulty addresses, initial misunderstanding regarding stamp duties, franking, etc., as well as inadequate liaison between the Army Postal Service and the Quartermaster General affected the smooth functioning of the Military Postal Organisation - in some cases temporarily and in others, more permanently.

The Rebellion period, however, provided an invaluable schooling for the Military Postal Service.

The avaliable information regarding the Military Postal Service during the actual campaign in German South-West Africa is unfortunately not always complete enough to provide a comprehensive picture. An attempt has been made, however, to give a résumé of the field post offices which were in operation for longer or shorter periods of time during the operation. In this regard Capt. L. Simenhoff, E.D., B.A., F.R.P.S.L., R.D.P. (S.A.A.) did pioneer work for some years and reference was frequently made to his researches in compiling this surviey.

From the available archivalia, in spite of inadequacy, the conclusion was reached that the Army Postal Service, taking all circumstances into consideration, in fact accomplished much to bis proud of and always did its utmost to render a satisfactory and efficient service.

The urgend need for regular contacts between the soldier in the field and his family and friends is of the utmost importance as a morale builder. This was quickly realised by the military authorities and officers of The South African Field Postal Service and Telegraphy Corps were fully aware of the importance of this factor and acted accordingly.
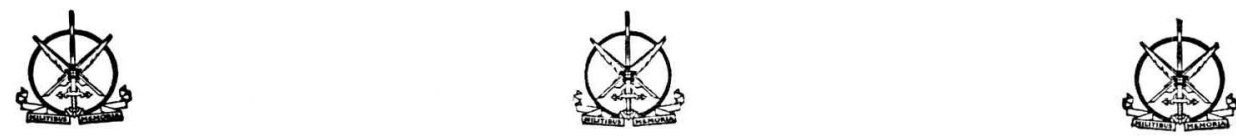


\section{NOTES}

1. E. Rosenthal and E. Blum, Runner and Mailcoach, Postal History and Stamps of Southern Africa (Cape Town, Johannesburg, London, 1969), p.1.

2. Ibid. p. 2.

3. Ibid. pp. 4-5.

4. Ibid. p. 6.

5. Ibid. p. 9.

6. Ibid. p. 10.

7. Ibid. p. 116.

8. Ibid. pp. 42-47.

9. Official Year Book of the Union of South Africa 1910-1916, (Pretoria, 1918). Chapter XIX (Posts, Telegraphs and Telephones), pp. 592-603.

10. See Statutes of the Union of South Africa 1910 and 1911, (Pretoria, 1911). pp. 258-350.

11. See note 9, p. 5-93.

12. See note 9, p. 601.

13. The Union of South Africa and the Great War 1914-1918, (Pretoria, 1924), p. 25.

14. Ibid. p. 13.

15. Ibid. p. 15 .

16. Ibid. p. 19.

17. C.B.E. London Gazette, No. 31296, 15th May, 1919. Mentioned in despatches, L.G., 22nd August, 1918. The C.B.E. was awarded to Maj. Sturman in his capacity as Honorary Secretary, South African Gifts and Comforts Committee. Commander 1 Section S.A. Field Telegraph and Postal Corps was Maj. (later Lt.-Col.) Norman Harrison, C.M.G., D.S.O., who took part in the campaigns in South-West Africa and France, was Honorary Colonel South African Corps of Signals, A.C.F. from 5th August, 1938 and died in 1949 in the rank of Lieutenant-Colonel.

18. Government Notice No. 1514, 7th September, 1914. A number of officers were transferred from the supernumerary list to the Corps for active service on 30th September, 1914. No indication was given, however, whether they were destined for Section 1 or 2 of the Corps. They were:

Maj. N. Harrison, Maj. A. E. Sturman, Capt. A. D. Fosbray, Capt. J. W. French, Capt. H. Frew, Capt. T. R. McArthur, Capt. F. V. R. Romilly, Lt. M. E. Becker, Lt. F. A. Cooke, Lt. J. A. Dingwall, Lt. A. G. Butridge, Lt. S. Hancox, Lt. C. H. Holder, Lt. J. R. Howitson, Lt. A. J. Jeanes, Lt. E. Lesl, Lt. J. Milne, Lt. B. J. Tait, Lt. J. F. Tierney, Lt. C. W. Wannell.

19. The Manual of Army Postal Services (War), mentioned in Army Orders (War Office), September, 1937.

20. Union Defence Force. Order No. 1. Army Post Office. Cape Town, 23rd September, 1914.

21. Ibid., para. 4. Posted No. 1 Base Post Office, Cape Town: Lt. J. F. Tierney; No. 2 Army Base Post Office, Port Nollith: Capt. F. V. R. Romilly, Lt. C. W. Wannell; No. 3 Army Base Post Office, Upington: Capt. J. W. French, Lt. J. A. Rademan; No. 4 Army Base Post Office, Lüderitzbucht: Capt. H. Frew, Lt. J. W. Howitson; No. 5 Army Base Post Office, Swakopmund: Maj. J. A. Venning, Lt. E. Leslie.

22. Ibid., para. 6.

23. Regarding the powers and duties of the Postmaster General: See Act No. 10 of 1911 , Chapter 1.

24. The Union of South Africa and the Great War 1914-1918, (Pretoria, 1924), p. 15 et seq.

25. No other list was found among available archivalia. In his accompanying letter, the Quartermaster General stated: Additional lists will be forwarded to you as they become available.

26. Partly illegible.

27. See 1: Brig-General J. J. Collyer, C.B., C.M.G., D.S.O., The Campaign in German South-West Africa 1914-1915, (Pretoria, 1937).

28. Official Year Book of the Union of South Africa, (Pretoria, 1920). No. 3 - 1919; pp. 416417.

29. The Union of South Africa and the Great War 1914-1918, (Pretoria, 1924); p. 60.

30. Collyer, op cit, pp. 153-154. 
31. The undated publication of Capt. L. Simenhoff, E.D., B.A., F.R.P.S.L., R.D.P. (S.A.A.). The "Occupational postmarks of the Mandated Territory of South-West Africa" (Middelburg, Tvl., reprinted, pp. 24), pp. 7-8 where the following sequence is given under the heading, Type 11. Field Post Office: 1. De Aar, 2. Beaconsfield, later Upington, 3. Bloemfontein, 4. Bethlehem, 5. Tempe, 6. Ramansdrift, 7. Kuruman, 8. Garup or 18, 9. Steinkopf, 10. Green Point Common, 11. Namies, 12. Norries, 13. Swakopmund, 14. Groote Schuur, Rosebank or Rondebosch, 15 General Hospital Wynberg, 16. Schuitdrift, 17. Wynbergkamp, 19. Bushmansputs, 21.2 Mounted Brigade, 22. Husali, 23. Ukamas, 24. Jerusalem, 25. Namib, 26. Gibeon and Seeheim, 27. 3 Mounted Brigade, 31. Marienthal, 37. Rehoboth, Kub, 41. Karibib, 44. Okahandja, 47. Usakos, 50. Omaruru, 52. Kalkfield, 59. Otjiwarongo, 59. Otavifontein, 60. Grootfontein, 61. Otari.

32. Official Year Book of the Union of South Africa, (Pretoria, 1920). No. 3 - 1919, pp. 908-909.

33. In the same circular mention was made of the fact that money could be sent to troops by way of British postal orders. These postal orders could be cashed at any Military Post Office in the field. It was recommended that letters containing postal orders, however, be registered and that no coins or bank notes should be transmitted through the post. A warning was given that delays could possibly be expected in the delivery of registered mail and that money should preferably be transmitted in official registered envelopes.

34. In this circular mention was also made of the necessity of addressing letters to troops in the Transvaal and the Orange Free State, care of the Army Post Office, Johannesburg.

35. On 28th October, 1914, the Secretary of the East London Chamber of Commerce also advocated the despatch of mail free of charge to troops. On 19th November, 1914, the Quartermaster General replied that the matter had been laid before the Postmaster General. It was already a considerable concession that the mail despatched by the troops was handled, conveyed and delivered free of charge and that the Railways also transported gift parcels to these troops free of charge.

36. The notice was sent to the following persons: Col. Dirk van Deventer (Calvina), Col. Ben Bouwer (Upington), Col./Cmdt. Alberts (Kimberley), Col./Cmdt. Badenhorst (Kopies,), Col. Brits (Kroonstad), Col./Cmdt. Botha (Kroonstad), Col. Brand (Theunissen), Col./Cmdt. Celliers (Kimberley), Col./Cmdt. Jordaan (Middelburg), Col./Cmdt. Lemmer (Makwassie), Col./Cmdt. Mentz (Theunissen), Col./Cmdt. T. Smuts (Vereeniging), Cmdt. Botha (Harrismith), Cmdt. Buitendach (Potchefstroom), Cmdt. Boshof (Schweizer Reneke), Cmdt. Cullinan (Vryburg), Cmdt. de Beer (Taungs), Cmdt. du Toit (Makwassie), Cmdt. Erasmus (Pietersburg), Cmdt. Ferreira (Utrecht), Cmdt. Frylïnch (Kuruman), Cmdt. Geyser (Warmbath), Cmdt. Geldenhuis (Nylstroom), Cmdt. Grobler (Kopjes), Cmdt. Hofman (Makwassie), Cmdt. Howell (Harrismith), Cmdt. Joubert (Dullstroom), Cmdt. Jones (Warmbath), Cmdt. van Heerden (Rustenburg), Cmdt. van Tonder (Brits), Cmdt. Yssel (Schweizer Reneke), Cmdt. Coleman (Mafeking), Cmdt. de Kock (Mafeking), Cmdt. Scott (Griekwastad).

37. Mention was also made to the effect that members of units performing garrison duty in the Cape Peninsula or on duty in the prisoner of war camp in Pietermaritzburg could still send unstamped letters after 1st September ,1915, if such letters were posted through the duty room and franked with the regimental stamp. Members of the Expeditionary Forces (overseas) could send letters in the Union free of charge, provided such letters were marked "South African Expeditionary Forces Overseas, on active duty."

38. Where delivery appeared to be impossible, the postal articles concerned were returned weekly to the office for undelivered mail. This procedure dated from 7 th October, 1914.

39. In the report no ranks were indicated.

40. On 9th November, 1914, the burghers of the Heidelberg Commando telegraphed General Louis Botha to enquire why they did not receive any letters.

On 12th November confusion arose in the distribution of mail for units stationed at Pretoria. It was decided to sort the mail for each unit at the General Post Office. The mail orderlies could then obtain the mail at the poste restante section. On 27th November the Quartermaster General requested the Postmaster General, Pretoria to keep back letters for U.D.F. members in the field until an opportunity presented itself of delivering the letters to the addressees. 
41. On 19th January, 1915, it was made known in Defence Orders that enquiries regarding undelivered letters should be directed to the Director, Information Bureau, Defence Headquarters, Pretoria. Corps orders announced that undeliverable letters had to be returned to No. 1 Base Post Office, Cape Town.

On 9th February, 1915, it was announced in the same orders that letters for decsased troops had to be returned to the same Base Post Office after endorsement by the officers commanding.

42. On 28th October, 1914. it was made known in the Orders of the Military Postal Service that all mail bags had to be returned to No. 1 Base Post Office.

On 8th February the aforesaid orders announced that, in view of the fact that the military mail bags were not being returned in sufficient quantities, those mail bags received by the military postal service from civilian post offices could not be returned forthwith.

43. At that stage Maj. Vennings was attached to the Northern Force.

44. From 8th February reverse charge radio and cablegrams (with destinations in the Union of South Africa) could be accepted at Lüderitzbucht and Walvis Bay (including Swakopmund) if the consignors could satisfy the Commander Advanced Base Post Office that they did not have sufficient funds to prepay the costs. The names, surname, rank, company or other identification had to be obtained by the officer accepting the telcgramme. These telegrammes had to be classified under COLLECT.
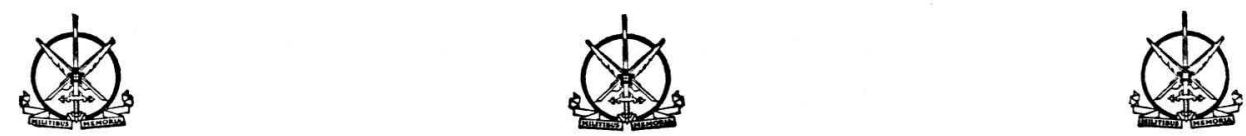


\section{APPENDIX}

1. Union Defence Force. Order No. 1 Army Post Office. Cape Town, 23rd September, 1914.

2. Ibid., Order No. 2 Army Post Office. Cape Town, 30th September, 1914.

3. Ibid., Order No. 3 Army Post Office. Cape Town, 7th October, 1914.

4. Ibid., Order No. 4 Army Post Office. Cape Town, 14th October, 1914.

5. Ibid., Order No. 5 Army Post Office. Cape Town, 21st October, 1914.

6. Ibid., Order No. 6 Army Post Office. Cape Town, 28th October, 1914.

7. Ibid., Order No. 7 Army Post Office. Cape Town, 5th November, 1914.

8. Ibid., Order No. 8 Army Post Office. Cape Town, 11th November, 1914.

9. Ibid., Order No. 9 Army Post Office, Cape Town, 18th November, 1914.

10. Ibid., Order No. 10 Army Post Office. Cape Town, 23rd November, 1914.

11. Ibid., Order No. 11 Army Post Office, Cape Town, 2nd December, 1914.

12. Ibid., Orders No. 12 Army Post Office, Cape Tofn, 9th December, 1914.

13. Ibid., Orders No. 16 Army Post Office, Cape Town, 22nd January, 1915.

14. Ibid., Orders No. 17 Army Post Office, Cape Town, 8th February, 1915.

15. Ibid., Orders No. 18 Army Post Office, Cape Town, 19th February, 1915.

16. Ibid., Orders No. 19 Army Post Office, Cape Town, 3rd March, 1915.

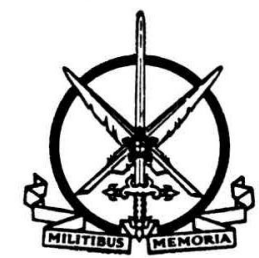




\section{UNION DEFENCE FORCE}

ORDER NO. 1.

\section{ARMY POST OFFICE}

Cape Town,

23 September, 1914.

(Orders by Major E. A. Sturman, Director of Postal Services, Officer Commanding, South African Postal Corps.)

\section{APPOINTMENTS}

Mr. E. A. Sturman, Acting Secretary, Director of Posts and Telegraphs, to be Officer Commanding, with the rank of Major in the Union Defience Force.

Major J. A. Venning, second in command 13th Mounted Rifles, to be seconded for duty with the South African Postal Corps.

Messrs F. V. R. Romilly, J. W. French and H. Frew to be Captains.

Messrs J. F. Tierney, J. R. Howitson, E. Leslie, J. A. Rademan and C. W. Wannell to be Lieutenants.

2. HEADQUARTERS. Town.

Headquarters have been established at the General Post Office, Cape

3. LOCATIONS.

Base Post Offices have been established at the following points:

Base No. 1. CAPE TOWN.

Base No. 2. PORT NOLLOTH - Force A.

Base No. 3. UPINGTON - Force B.

Base No. 4. LUDERITZBUCHT - Force C.

Base No. 5. SWAKOPMUND - Force D.

All lead sealing pliers will bear the number of the base at which they are in use.

4. POSTINGS.

No. 1 Base Post Office, Cape Town,

Lieut. J. F. Tierney.

No. 2 Advance Base Post Office, Port Nolloth, Capt. F. V. R. Romilly and Lieut. C. W. Wannell.

No. 3 Advance Base Post Office, Upington, Capt. J. W. French and Lieut. J. A. Rademan.

No. 4 Advance Base Post Office, Luderitzbucht, Capt. H. Frew and Lieut. J. R. Howitson.

No. 5 Advance Base Post Office, Swakopmund, Major J. A. Venning and Lieut. E. Leslie.

\section{FIELD CENSORS.}

Officers in charge of Base Post Offices at Port Nolloth, Upington, Luderitzbucht and Swakopmund are appointed Field Censors, and Quarter-MasterGeneral's instructions No. D.2530 referring to Postal Censorship in the field, which have already been issued to all concerned, must be strictly carried out. 


\section{ADVANCE BASE POST OFFICES.}

Officers in charge of Advance Base Post Offices will, in consultation with Force Commanders, make adequite provision for affording Post Office facilities in the field. Where necessary, non-commissioned officers or men of the S.A.P.C. may be allocated to such points as may be selected by the Column Commanders for such purpose,but so far as possible it should be arranged to establish such Field Post Offices at places where Post Offices previously existed in G.S.W. Africa. The Union Post Office Guide should be referred to for guidance in this respect.

\section{INSTRUCTIONS.}

Circulars will be issued from time to time containing instructions respecting the Postal work of the Corps. The Circulars will be numbered consecutively and copies will be sent to all concerned.

By Order.

J. A. VENNING, Major, for O.C., South African Postal Corps. 


\section{UNION DEFENCE FORCE}

ORDER NO. 2.

\section{ARMY POST OFFICE}

Cape Town,

30 September, 1914.

(Orders by Major E. A. Sturman, Director of Postal Services, Officer Commanding, South African Postal Corps.)

\section{PROMOTIONS.}

The following promotions are hereby notified for general information.
F. Robinson
to be C. Sergt. Major.
A. Colenso
to be C. Q. M. Sergt.
V. R. Woods
S. Pollock
H. H. Murphy
C. A. Lanham
A. C. Stanley
J. H. Weaver
H. C. Smith
J. H. Dawson

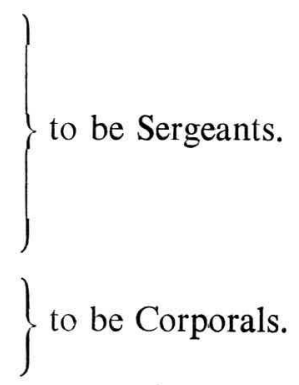

to be Sergeants.

2. POSTINGS.

$\begin{array}{lll}\text { No. 1. Base } & \text { C. Sergt. Major } & \text { F. Robinson. } \\ & \text { C. Q. M. Sergt. } & \text { A. Colenso. } \\ & \text { Sergt. } & \text { V. R. Woods. } \\ & \text { Sergt. } & \text { S. Pollock. } \\ \text { Corpl. } & \text { H. C. Smith. } \\ \text { No. 2. Base } & \text { Sergt. } & \text { H. H. Murphy. } \\ \text { No. 3. Base } & \text { Sergt. } & \text { C. A. Lanham. } \\ \text { No. 4. Base } & \text { Sergt. } & \text { A. C. Stanley. }\end{array}$

\section{LOCATIONS.}

The establishment of No. 5 Advance Base Post Office, Swakopmund, referred to in Regimental Orders No. 1 has been postponed.

\section{CAP AND SHOULDER BADGES.}

Cap and Shoulder Badges at a cost of $7 \mathrm{~s} .6 \mathrm{~d}$. and 3s. 6d. respectively are now available, and will be issued by the C.Q.M. Sergt. on application.

Cash must be remitted in payment.

5. CHEVRONS.

Chevrons are now available for issue to those members entitled thereto.

6. LEAD SEALING PLIERS.

Additional Lead Sealing Pliers have now been allotted as follows :- 


\section{REMOVAL OF ADVANCE BASE POST OFFICE.}

The Advance Base Post Office established at Port Nolloth has been removed to Steinkopf as from 26th September, 1914.

\section{CIRCULARS.}

Circular No. 1 issued to officers in Charge of Base and Field Base Post Offices, contains general instructions to be observed by members of this Corps in charge of all offices in the Field, and should be carefully studied, special mention being directed to the paragraph dealing with Private correspondence.

\section{REGISTERED INDICATORS.}

The following Telegraphic Addresses have been registered :-

DIRAPO.-Director of Postal Services, Cape Town.

ARMYPO.-For Base, Advance Base, and Field Offices opened or subsequently opened within the Union or in German South-West Africa.

10. Any member of the Corps who has not made arrangements regarding his pay should do so at once, by completing a Stop Order, or arranging for payment by means of a recognised Power of Attorney.

\section{By Order.}

JAMES A. VENNING, Major. 


\title{
UNION DEFENCE FORCE
}

ORDER NO. 3.

\section{ARMY POST OFFICE}

\author{
Cape Town, \\ 7th October, 1914.
}

(Orders by Major E. A. Sturman, Director of Postal Services, Officer Commanding, South African Postal Corps.)

\section{POSTINGS.}

\author{
$\left.\begin{array}{l}\text { Sergt. J. H. Weaver } \\ \text { L/Cpl. R. P. A. Sweet }\end{array}\right\} \quad$ Base No. 2.
}

\section{EQUIPMENT.}

All members of the Corps should now be in possession of full kits, and officers in charge of the various Field Base Offices, must see that every rank under their respective commands is fully equipped. No excuse will be taken for any cases discovered after the issue of this order.

\section{DEFICIENCES.}

Any loss or deficiency of kit must be reported in writing as soon as discovered, and made good by means of a special requisition, the cost being debited to the individual concerned, and another issue made on repayment.

In the case of the loss of any article of equipment( which is Government property) a special report must be prepared, by the officer in charge of the individual concerned, and a Board will be convened to enquire into the circumstances.

\section{CARE OF ARMS.}

Every member must see that his rifle and bayonet are kept scrupulously clean, and officers will be held responsible for a periodical inspection of same.

\section{ESTABLISHMENT OF FIELD POST OFFICES.}

The establishment of every Field Post Office must be notified at once to Cape Town by telegraph, likewise the closing of an office, giving dates and name of the N.C.O. in charge.

\section{WEEKLY REPORTS.}

On and after the receipt of Regimental Order No. 3, Advance Base Post Oîfices must furnish every seven days, a condensed resumé of happenings, covering the previous seven days viz:- Sunday to Saturday of each week, and post same per first available opportunity.

Bases 2, 3, and 4 must send in a report covering the period from the establishment of each respective base, up to the time of commencing the weekly reports, giving as far as can be remembered, the principal events which have happened, and the disposition of the staff.

\section{R.L.O. RETURNS.}

All insufficiently addressed matter, and correspondence which cannot 
Undelivered parcels must be returned to Base Post Office No. 1 for treatment and not to the Returned Letter Office. The reason for their non-delivery should be clearly indicated.

Officers holding credit stocks must in all cases retain a record of the number and series of Postal Orders held, and members in charge, will be held responsible that this record is strictly maintained.

By Order.

JAMES A. VENNING, Major. 


\section{UNION DEFENCE FORCE}

ORDER NO. 4.

\section{ARMY POST OFFICE}

Cape Town,

14th October, 1914.

(Orders by Major E. A. Sturman, Director of Postal Services, Officer Commanding, South African Postal Corps.)

\section{POSTINGS.}

Lieutenant J.A. Rademan to Kenhardt.

Lieutenant E. Leslie to Base No. 3.

Captain G. H. M. Muir to Base No. 1 for Government and Field Censorship.

The postings of Sergt: J. H. Weaver and L/Cpl. R. P. A. Sweet as notified in Corps Order No. 3 have been cancelled, and they are hereby posted to Base 3.

\section{WEEKLY REPORTS.} form S.88

Weekly Reports referred to in Corps Order No. 3 should be made on

\section{PARCELS.}

The paragraph appearing in Circular 1 page 2, Parcels, will on and from 1st proximo be cancelled. Inland Parcels from that date in both directions will be treated in the same manner as ordinary letters.

Redirections from one unit to another are free.

Parcels addressed to deceased and unknown persons must be promptly returned to the senders free of postage.

\section{CREDIT STOCKS.}

Officers in charge of Field Base Offices must see that Credit Stocks are frequently replenished, and on no account must cash, the result of sales, be allowed to accumulate except a small quantity of silver retained for change. Exchanges of cash with Field Paymasters must be made as frequently as possible and the cheques received remitted at once as described in Circular No. 1.

Credit Stocks must be checked frequently and a report forwarded to Cape Town after each check.

A monthly return of unissued stocks must be rendered on the last day of each month to this Office.

5. BLUE PENCIL.

Blue Pencil should be utilised as far as possible on address labels.

By Order. 


\section{UNION DEFENCE FORCE}

ORDER NO. 5.

\section{ARMY POST OFFICE}

Cape Town,

21st October, 1914.

(Orders by Major E. A. Sturman, Director of Postal Services, Officer Commanding, South African Postal Corps.)

\section{ENROLMENT.}

A. V. Stanley, Regimental No. 37.

2. PROMOTIONS.

A. V. Stanley to be Lance Corporal.

3. POSTINGS.

Lance Corporal A. V. Stanley is posted to Base 1.

Lance Corporal T. H. Fox is transferred from Base 1 to Base 4.

\section{ESTABLISHMENT OF FIELD POST OFFICE.}

A Field Post Office was established at Prieska on 15th October, 1914.

A Field Post Office was established at Port Nolloth on 16th October, 1914.

\section{UNPAID POSTAGE.}

The Treasury has decided that all unpaid and insufficiently prepaid postal matter, addressed to Troops in the Field, must be surcharged according to the Union tariff, and the collections brought to account by means of the Postage Due Stamps.

Each Advance Base and Field Post Office must hold a credit stock of Postage Due labels.

The last three lines on page 3 of Circular No. 1 should therefore be deleted.

\section{REMITTANCES.}

Authority has been received for cash received on Account of Stamp and Postal Order sales being handed over to Field Paymasters, who will give a receipt therefore to officers in charge of Advance Base Offices.

These receipts must be remitted to the Controller, C.P.O. Cape Town as portion of a remittance when applying for fresh supplies. Papers $95341 / 14$, Defence C 5/9397.

\section{FURNITURE RETURNS}

Advance Base Offices are hereby directed to prepare at once furniture returns, covering offices under their respective controls, and send same to Head Quarters. All rubber and steel stamps to be enumerated and impressions given.

By Order. 


\title{
UNION DEFENCE FORCE
}

ORDER NO. 6.

\section{ARMY POST OFFICE}

\author{
Cape Town,
}

28th October, 1914.

(Orders by Major E. A. Sturman, Director of Postal Services, Officer Commanding, South African Postal Corps.)

1. PROMOTION.

C. Sergt. Major F. Robinson to be Lieutenant.

2. POSTINGS.

Lieut. F. Robinson, No. 5 Advance Base Post Office.

3. TRANSFERS.
Lt. C. W. Wannell
Corp. J. H. Dawson
L/c J. P. J. Moloney
From Base 2 to Base 1.

\section{LOCATIONS.}

Advance Base Post Office No. 2 has been moved from Steinkopf to Port Nolloth from 25th instant.

Field Post Office at Prieska was transferred on the 26th instant to Marydale, and thence to Kenhardt on 28th idem.

A Field Post Office was established at Kakamas on the 27th instant.

A Field Post Office will be established at Birdfield on the 30th inst.

Advance Base Post Office No. 5 has been established at Pretoria.

\section{PARCELS.}

Advance Base and Field Post Offices are reminded of the instructions appearing in Order No. 4, and to follow closely, details laid down as to treatment of parcels from 1st proximo, (papers 102469/14). Parcel C and List Books, containing entries up to 31st instant, must be returned to Head Quarters for File purposes.

6. BAGS.

The attention of all ranks is drawn to the necessity for returning promptly all empty bags to Base 1, per first despatch after receipt.

\section{LOOSE LETTERS.}

Splscial care must be exercised by despatching officers to see that bundles are securely tied.

8. CENSORSHIP.

Under no circumstances should letters or postcards, awaiting censorship, be held over by Field Censors when a mail is due to be despatched, but should be sent forward to Base 1 Cape Town, under a special label endorsed "To be censored."

It is to be noted, that the recently issued Force Order confining Troops to the use of Postcards only has been withdrawn.

By Order. 


\section{UNION DEFENCE FORCE}

ORDER NO. 7.

\section{ARMY POST OFFICE}

Cape Town,

5th November, 1914.

(Orders by Major E. A. Sturman, Director of Postal Services, Officer Commanding, South African Postal Corps.)

\section{PROMOTION.}

Sergt. S. Pollock to be C. Sergt.-Major vice F. Robinson promoted.

L/Cpl J. P. J. Moloney to be Corporal.

\section{TRANSFERS}

Advance Base Post Office No. 5 has been transferred to Johannesburg.

\section{LOCATIONS.}

Field Post Office at Birdfield was closed on 2nd instant.

Temporary Field Post Office was opened at Kraaifontein on 2nd instant and closed on 4th idem.

Field Post Office at Kenhardt was closed on 4th instant.

Field Post Office has been established at Bloemfontein from 5th inst.

\section{DRESS}

Khaki Drill may be taken into wear from 1st November until further notice.

Tunics and trousers may be obtained on requisition, but can only be issued on repayment, and must not be regarded as a free issue.

\section{CORRESPONDENCE.}

Considerable difficulty has been experienced in the Base Post Office, in in effecting the prompt distribution of mail matter for individuals, whose correspondence is insufficiently addressed. Members in charge of Field Base, and Field Post Offices, should draw the attention of addressees, and Post Orderlies to such mail matter when effecting delivery.

Complaints received in many cases are due entirely to such causes.

\section{REGIMENTAL ROLLS.}

Officers in charge of Bases 2 and 4, are hereby requested to obtain and submit nominal rolls of Corps, within their respective areas. Adjutants of Regiments will doubtless render valuable assistance in this direction.

This information is to be forwarded to Base Cape Town, for record purposes.

\section{CENSORSHIP.}

Letters originating from officers in the Field, are not in future to be opened by Field Censors, but sent under separate cover, addressed to the Chief Field Censor, Cape Town, cover endorsed "Officers letters."

By Order. 


\section{UNION DEFENCE FORCE}

ORDER NO. 8.

\section{ARMY POST OFFICE}

Cape Town,

11th November, 1914.

(Orders by Major E. A. Sturman, Director of Postal Services, Officer Commanding, South African Postal Corps.)

1. ENROLMENTS.

E. F. Barry

W. M. Milne

I. W. A. Morison

W. R. Portingale

A. E. de Gruchy

H. Hembury

L. J. Allen

A. V. Jeffery

F. W. Andreas

J. H. B. Norwell

2. PROMOTIONS.

W. M. Milne

L. J. Allen

A. V. Jeffery

E. F. Barry

W. R. Portingale

A. E. de Gruchy

H. Hembury

F. W. Andreas

J. H. B. Norwell
Regimental No. 38.

Regimental No. 39.

Regimental No. 40.

Regimental No. 41.

Regimental No. 42.

Regimental No. 43.

Regimental No. 44.

Regimental No. 45.

Regimental No. 46.

Regimental No. 47.

3. TRANSFERS.
to be Sergeant.
to be Sergeant.
to be Corporal.
to be $\mathrm{L} / \mathrm{Cpl}$.
to be $\mathrm{L} / \mathrm{Cpl}$.
to be $\mathrm{L} / \mathrm{Cpl}$.
to be $\mathrm{L} / \mathrm{Cpl}$.
to be $\mathrm{L} / \mathrm{Cpl}$.
to be $\mathrm{L} / \mathrm{Cpl}$.

L/Cpl. E. F. Barry

L/Cpl. W. R. Portingale

L/Cpl. A. E. de Gruchy

Cpl. A. J. Dawson

Sergt. L. J. Allen

Cpl. A. V. Jeffery

L/Cpl. F. W. Andreas

L/Cpl. J. H. B. Norwell

\} posted to Field Base No. 2a.

posted to Base No. 1.

)

posted to Field Base No. 5.

\section{LOCATIONS.}

Advance Base Post Office No. 2 has been removed from Port Nolloth to O'okiep from 9th instant.

Field Post Office opened at Steinkopf on 6th inst.

\section{OVERSEA CORRESPONDENCE.}

It is observed that many men in the Field are under the impression free postage extends beyond the borders of the Union of South Africa. Such is not the case and all ranks should as far as possible make it generally known that such correspondence must be prepaid otherwise the addressees are called upon to pay the deficiency.

By Order. 


\section{UNION DEFENCE FORCE}

ORDER NO. 9.

\section{ARMY POST OFFICE}

Cape Town,

18th Nov. '14.

(Orders by Major E. A. Sturman, Director of Postal Services, Officer Commanding, South African Postal Corps.)

1. ENROLMENTS.

W. S. Potter

P. J. Henchie

G. J. Sumption

R. C. Isemonger

H. W. Willmer

W. F. Moon

\section{PROMOTIONS.}

L/Cpl. W. J. Davies

L/Cpl. A. W. Goldie

L/Cpl. A. V. Stanley

Pte. W. S. Potter

Pte. P. J. Henchie

Pte. G. J. Sumption

Pte. R. C. Isemonger

Pte. H. W. Willmer

Pte. W. F. Moon

3. TRANSFERS.

L/Cpl. G. J. Sumption

L/Cpl. R. C. Isemonger

L/Cpl. H. W. Willmer

L/Cpl. W. F. Moon

Cpl. A. V. Stanley

Sgt. W. M. Milne

L/Cpl. W. S. Potter

L/Cpl. P. J. Henchie

Lieut. J. A. Rademan

L/Cpl. E. F. Barry

Capt. G. H. M. Moir
Regimental No. 48.
Regimental No. 49.
Regimental No. 50.
Regimental No. 51.
Regimental No. 52.
Regimental No. 53.

to be Corporal.

to be Corporal.

to be Corporal.

to be $\mathrm{L} / \mathrm{Cpl}$.

to be $\mathrm{L} / \mathrm{Cpl}$.

to be $\mathrm{L} / \mathrm{Cpl}$.

to be $\mathrm{L} / \mathrm{Cpl}$.

to be $\mathrm{L} / \mathrm{Cpl}$.

to be $\mathrm{L} / \mathrm{Cpl}$.

posted to Base No. 1. posted to Base No. 1. posted to Base No. 1. posted to Base No. 1. posted to Base No. 2. posted to Field P.O. 1. posted to Field P.O. 1. posted to Field P.O. 1. posted to Field P.O. 2. posted to Field P.O. 2.

13th Mounted Rifles returns to Regimental duty from 18th instant.

\section{FIELD POST OFFICES.}

Field Post Office No. 1 was opened at De Aar on the 16th instant.

Field Post Office No. 2 Orange Fres State on 16th instant.

\section{CIVIL POST OFFICES.}

Kimberley office is specially dealing with Army Post Office correspondence from 16th instant.

A Civil Post Office has been opened at Booysens Camp from 17th instant. 
6. CIVILIAN POST OFFICE MONTHLY CIRCULAR.

The Union Monthly Post Office circular has been sent to Army Post Offices, and must be filed in conjunction with Regimental Orders.

Officers in charge of Offices will be held responsible to see that each issue is read and noted by members under their respective commands.

\section{RECORDS.}

Officers in charge of Field Base Offices are held responsible for the return and safe custody of records, when positions are vacated, or Field Offices closed.

Such records to be reforwarded to Cape Town, after examination by the Field Base Offices.

\section{UNDELIVERED CORRESPONDENCE.}

Correspondence which cannot be delivered, through insufficiency of address, should be sent to Base 1, labelled "blinds."

\section{UNIT POSITIONS.}

Considerable assistance to Base 1, could be given by Field Offices, if paragraph 2 of Army Post Office Circular No. 1, were given greater attention viz :-

The prompt advice to Cape Town of all units operating upon each Field Base, and notice of impending departures, together with name of new destination.

Such information must be send in Code daily, and if no changes a telegram should nevertheless be sent, stating "Positions unchanged."

\section{By Order.}

JAMES A. VENNING, Major. 


\section{UNION DEFENCE FORCE}

ORDER NO. 10.

\section{ARMY POST OFFICE}

Cape Town,

25th May, '14.

(Orders by Major E. A. Sturman, Director of Postal Services,

Officer Commanding, South African Postal Corps.)

1. ENROLMENTS.

H. G. Mathieson

J. Keenan

S. J. Snashall

D. Thompson

J. Carver

H. J. Palmer

A. MacLachlan

R. McIntyre
Regimental No. 54.

Regimental No. 55.

Regimental No. 56.

Regimental No. 57.

Regimental No. 58.

Regimental No. 59.

Regimental No. 48.

Regimental No. 49.

2. PROMOTIONS.

Pte. H. G. Mathieson

Pte. J. Keenan

Pte. S. J. Snashall

Pte. D. Thompson

Pte. J. Carver

Pte. H. J. Palmer

Pte. A. MacLachlan

Pte. R. McIntyre

3. TRANSFERS.
L/Cpl. W. E. Batt
L/Cpl. R. A. East
L/Cpl. C. F. Pentz
L/Cpl. E. H. Harsh
L/Cpl. R. Lord

have been transferred to the Field Telegraph Section and are taken off the strength of the Postal Corps.

4. POSTINGS.
L/Cpl. H. G. Mathieson
L/Cpl. A. MacLachlan
Posted to Base 1.
L/Cpl. R. McIntyre
L/Cpl. J. Keenan
L/Cpl. D. Thompson
L/Cpl. J. Carver
Posted to Base 2.
L/Cpl. H. J. Palmer
L/Cpl. S. J. Snashall
L/Cpl. C. J. Conway
Postid to Base 3.
Transferred to Field P.O. 1.

\section{LOCATIONS.}

Field Post Office No. 2 Orange Free State was removed to Beaconsfield on the 19th instant, and retransferred to Upington, and placed under the control of Advance Base No. 3 from 23rd idem.

Advance Base P.O. No. 2 was retransferred from O'okiep to Steinkopf from 21 st instant. 


\section{ARRIVALS AND DEPARTURES.}

All arrivals and departures of staff must be notified at once by Telegraph, giving time and date, to Dirapo, Cape Town.

All members joining the Corps at Advance Base and.Field Post Offices must send per first mail to Headquarters, stop orders for adjustment of salary, full details of age, name, address and relationship of next of kin.

Failure to carry out this request may result in delay in the prompt payment of monies due to such member, either to himself or dependants.

\section{ATTENDANCE BOOKS.}

All Army Post Offices must keep an attendance record book, in the manner prescribed under the Civil Administration.

\section{COMMUNICATIONS.}

Instances have been brought to notice, where members of the Corps have communicated direct by Telegraph or Letter to Heads of other Departments on matters affecting Administrative affairs. It is hereby notified for general information that all such reports should be Addressed in the first instance to the Director of Postal Services, who will take such action as may be considered necessary.

\section{REGIMENTAL ORDERS.}

Sufficient copies of such Regimental Orders are sent to all Advance Base and Field Offices, and should be distributed to every member of the Corps, so that the instructions contained therein may be read and retained. Any member sent into the field to open an office will be cxpected to be in a position to refer to the instructions issued from time to time, and thus ensure uniformity of records and working.

\section{UNIT POSITIONS.}

Special reference was made to Orders No. 8 regarding the necessity for advising the movements of Troops, to ensure as little delay as possible to correspondence addressed to units in the Field. Authority has now been obtained, from the Quarter Master General, for the Unit Commanders to telegraph from the nearest Telegraph Office, information concerning their future movements, and all ranks are hereby directed to render such officers every possible assistance, and to explain the object and requirements of the Army Post Office in this direction.

Every opportunity should be taken to veil the movements as far as possible, so that no information of Military significance may be disclosed.

\section{FREE TRANSIT OF CERTAIN PARCELS.}

Commandos operating in the Field who have subsequently been equipped with uniform, are permitted to return their civilian clothing to their homes, provided that such parcels are properly packed, and addressed, and bear the name and commando of the sender. The size and limit of weight permitted by the parcel post regulation must not be exceeded and this concession must be confined to one parcel per man.

A record must be kept at all offices of such parcels in the parcel posted register, and made up in separate mails to the Army Post Offices at Johannesburg, Bloemfontein, De Aar or Cape Town, where steps will be taken to frank these articles to their respective destinations.

By Order. 


\section{UNION DEFENCE FORCE}

ORDER NO. 11.

\section{ARMY POST OFFICE}

Cape Town,

2nd Dec., '14.

(Orders by Major E. A. Sturman, Director of Postal Services, Officer Commanding, South African Postal Corps.)

1. ENROLMENTS.
L. A. Thomson
Regimental No. 27.
E. Buckle
A. F. McLachlan
Regimental No. 28.
M. Dowling
Regimental No. 29.
R. Bartholomew
Regimental No. 30.
W. Graham
Regimental No. 31.
Regimental No. 60.

2. PROMOTIONS.

Pte. L. T. Thomson

Pte. E. Buckle

Pte. A. F. McLachlan

Pte. M. Dowling

Pte. R. Bartholomew

Pte. W. Graham

to be Lance-Corporals.

3. TRANSFERS.

L/Cpls. W. F. Moon and A. McLachlan

Sergt. H. H. Murphy

transferred to Base 2a.

transferred to Base 1.

4. POSTINGS.
L/Cpl. L. A. Thomson
L/Cpl. A. F. McLachlan
L/Cpl. R. Bartholomew
L/Cpl. W. Graham
L/Cpl. M. Dowling
L/Cpl. E. Buckle
posted to Base 1.
posted to Base 2a.
posted to Field P.O. 1.

\section{LOCATIONS.}

Field Base 2a has been transferred from Bloemfontein to Kroonstad from 30th ultimo.

Field P.O. No. 3 has replaced Field Base 2a at Bloemfontein from 1st instant.

Field P.O. No. 4 has been established at Bethlehem from 1st instant.

\section{CREDIT STOCKS.}

Special attention is drawn to the instruction issued to officers in charge of Field Base Offices regarding Credit Stocks of Postal Orders and Stamps. On no account must large credit stocks be held by the Army Post Offices where Civil Offices are available for the convenience of Troops. 


\section{REDIRECTIONS}

Field Base and Field Post Offices must exhibit a notice in a promineni position, informing members of the Forces that redirections cannot be undertaken tor individuals who leave their regiments on discharge, transfer or for any other reason. They must leave their next address with the Orderly Room of their respective Regiments. redirections.

The Army Post Office cannot undertake to comply with individual

\section{REQUISITION FOR STORES.}

Requisitions for all classes of Postal Stores must be forwarded to Headquarters for approval and covering minuce, without such authority the Stores cannot be issued.

It is desired that each Field Base will as far as possible try to requisition not oftener than once a month, and to estimate their requirements for the next four weeks, and instruct subordinate Field Offices accordingly.

Any further requisition which may be found necessary must be treated as special and accompanied by a minute explaining necessity therefore.

The greatest care and economy must be exercised in all items involving expenditure. There are no free services.

\section{ADVANCE BASE OFFICES.}

In Regimental Orders No. 1 paragraph 6 an instruction appears regarding "Consultation with Force Commander". In case any misunderstanding should arise in connection therewith it is hereby notified that the A.Q.M.G. or D.A.Q.M.G. is the officer through whom all proposals regarding future movements of Field Bases and Field Post Offices should be made, and that officer's agreement obtained before advising the Director of Army Postal Services, Cape Town. The words "Force Commander" were intended to convey "the officer in charge of detached units when the Q.M.G.'s representative was not available."

\section{REGIMENTAL ORDERS.}

The instruction appearing under paragraph 9 of Regimental Order No. 10 , must be understood that any member of this Corps not in possession of previous orders must see that he makes manuscript copies of those paragraphs which have bearing on general routine work if detached for Field duty. Copies of previous orders are now exhausted.

\section{POST AND TELEGRAPH FRIENDLY SOCIETY.}

Members of this Society now serving with the Army Post Office Corps arc hereby notified that they must make adequate arrangements to meet premiums as they fall due, otherwise serious consequences may result therefrom if the rules of the Society are not complied with. They are recommended to arrange payment through their Local Secretaries.

By Order.

JAMES A. VENNING, 


\section{UNION DEFENCE FORCE}

ORDERS NO. $12 *$

ARMY POST OFFICE

Cape Town,

9th Dec., '14.

(Orders by Major E. A. Sturman, Director of Postal Services, Officer Commanding, South African Postal Corps.)

1. TRANSFERS.

Lieut B. Leslie

Sergt. J. H. Weaver

L/Cpl. A. MacLachlan

L/Cpl. C. J. M. Conway from Base 5 to Base 1. from Base 5 to Base 1 . from Base $3 \mathrm{~g}$ to Base 1 . from Field P.O. 1 to Base 1.

\section{ENROLMENTS.}

The enrolment of No. 29, L/Cpl. A. F. McLachlan has been cancelled.

\section{ENQUIRIES.}

It is observed in censoring, that the writers of letters complain that parcels sent to Troops fail to reach addresses. In a number of cases which have been enquired into, it has been found that the parcels in question were not entrusted to the Army Post Office, but sent through forwarding agencies, who in turn consigned the packages to the Officer in Charge of Comforts, Cape Town, who forwarded same by first available opportunity to the addressees; on the other hand, parcels in excess of the parcel post limits of weight, are forwarded by rail to Cape Town, addressed to the Army Post Office. These Parcels are not at any time dealt with by officers of this Corps, neither is the Army Post Office in any way responsible for their transit, or safe delivery to the addressees, and it should be made generally known to everyone conczrned, that only these parcels which are posted and prepaid at any Civil Post Office within the Union of South Africa, are forwarded by the Army Post Office with the same despatch as letters.

\section{DAMAGED PARCELS.}

All damaged parcels must be suitably endorsed at the Post Office whrre the same is observed, and a brief report forwarded to the Director of Army Postal Services, Cape Town. Where possible the addressee should be seen and explanation tendered, and the cover submitted for investigation if necessary.

\section{MISSORTING.}

There are now a number of units in the Field, which have been split up into sections, and, in some cases, second bastions of regiments have been raised, each having a separate destination. The attention of sorters is particularly drawn to the necessity for exercising the greatest care to present missorts, and unnecessary delays.

\section{ARRIVALS AND DEPARTURES.}

Attention is drawn to Regimental Order No. 10, section 6, which in many cases has been neglected by officers in charge of Field Base and Field Base Offices. Every movement must be communicated at once to Dirapo, Cape Town.

JAMES A. VENNING, Major. 


\title{
UNION DEFENCE FORCE
}

ORDERS. NO. 16.

\section{ARMY POST OFFICE}

\author{
Cape Town,
}

22nd Jany. '15.

(Orders by Major E. A. Sturman, Director of Postal Services, Officer Commanding, South African Postal Corps.)

1. ENROLMENTS.

\author{
W. B. Gough \\ S. J. de Villiers \\ H. E. Haagner \\ G. C. Glass \\ T. Pownseby \\ R. Cruickshanks \\ P. H. Hultzer \\ W. C. Stoffberg \\ J. A. H. Winson \\ W. Hodgson
}

$\begin{array}{lr}\text { Regimental Number } 62 . & 5.1 .15 . \\ \text { Regmiental Number } 63 . & 10.1 .15 . \\ \text { Regimental Number } 64 . & 10.1 .15 . \\ \text { Regimental Number } 65 . & 10.1 .15 . \\ \text { Regimental Number } 66 . & 10.1 .15 . \\ \text { Regimental Number 67. } & 11.1 .15 . \\ \text { Regimental Number 68. } & 11.1 .15 . \\ \text { Regimental Number 69. } & 18.1 .15 . \\ \text { Regimental Number 70. } & 19.1 .15 . \\ \text { Regimental Number } 71 . & 19.1 .15 .\end{array}$

2. PROMOTIONS.

$\begin{array}{ll}\text { No. } 28 & \text { L/Cpl. E. Buckle } \\ \text { No. } 34 & \text { L/Cpl. T. H. Fox } \\ \text { No. } 62 & \text { Pte. W. B. Gough } \\ \text { No. } 63 & \text { Pte. S. J. de Villiers } \\ \text { No. } 64 & \text { Pte. H. E. Haagner } \\ \text { No. } 65 & \text { Pte. G. C. Glass } \\ \text { No. } 28 & \text { Pte. T. Pownceby } \\ \text { No. } 67 & \text { Pte. R. Cruickshanks } \\ \text { No. } 68 & \text { Pte. P. H. Hultzer } \\ \text { No. } 69 & \text { Pte. W. C. Stoffberg } \\ \text { No. } 70 & \text { Pte. J. A. H. Winson } \\ \text { No. } 71 & \text { Pte. W. Hodgson }\end{array}$

to be Corporal

to be Corporal

to be Lance-Corporal

to be Lance-Corporal

to be Lance-Corporal

to be Lance-Corporal

to be Lance-Corporal

to be Lance-Corporal

to be Lance-Corporal

to be Lance-Corporal

to be Lance Corporal

to be Lance Corporal

21.1.15.

21.1.15.

5.1.15.

10.1.15.

10.1.15.

10.1.15.

10.1.15.

11.1.15.

11.1.15.

18.1.15.

19.1.15.

19.1.15.

3. POSTINGS.

L/Cpl. W. B. Gough

L/Cpl. S. J. de Villiers

L/Cpl. H. E. Haagner

L/Cpl. G. C. Glass

L/Cpl. T. Pownceby

L/Cpl. R. Cruickshanks

L/Cpl. P. H. Hultzer

L/Cpl. W. C. Stoffberg

L/Cpl. J. A. H. Winson

L/Cpl. W. Hodgson posted to Base 1, Cape Town posted to Base 1, Cape Town posted to Base 1, Cape Town posted to Base 1, Cape Town posted to Base 1, Cape Town posted to Base 1, Cape Town posted to Base 1, Cape Town posted to Base 2, O'okiep posted to Base 1, Cape Town posted to Base 1, Cape Town
5.1.15. 10.1.15. 10.1.15. 10.1.15. 10.1.15. 11.1.15. 11.1.15. 18.1.15. 19.1.15. 19.1.15. 
4. TRANSFERS.

Rank Name

Transferred

Date

From

To

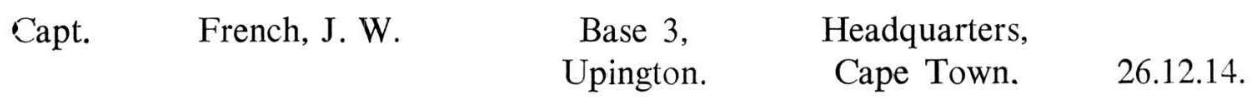

This cancels transfer notified in Army P.O. Orders No. 14.

Lieut. Wannell, C. W.

Army P.O.,

F.P.O. 4,

Johannesburg.

Bloemfontein.

1. 1.15 .

Lieut. Wannell, C. W.

F.P.O. 4,

Defence,

Bloemfontein. Pretoria.

7. 1.15 .

Lieut. Wannell, C. W.

Defence,

F.P.O. 1,

Pretoria.

De Aar.

16. 1.15 .

Sgt. Murphy, H. H.

Base 1,

Base 5,

Cape Town.

Walvis Bay.

17. 1.15 .

Sgt. $\quad$ Allen, L. J.

Army P.O.,

Base 1,

Johannesburg.

Cape Town.

16. 1.15 .

Sgt.

Milne, W. M.

F.P.O. 1,

Base 1,

De Aar.

Cape Town.

18.1. 15 .

$\mathbf{L} / \mathrm{Cpl}$ Keenan, $\mathbf{J}$.

Base 1,

Base 5,

Cape Town.

L/Cpl. Matthews, A. W.

Base 3,

Walvis Bay.

17. 1.15 .

Upington.

Base 1,

Cape Town.

14. 1.15 .

L/Cpl. McIntyre, R.

Base 1, Cape Town.

Base 4, Luderitz.

19. 1.15 .

L/Cpl. Bartholomew, R.

Base 1,

Cape Town.
Base 4,

Luderitz.

19. 1.15 .

\section{OPENING AND CLOSING OF FIELD POST OFFICES.}

Designation

Army Field P.O. 6 Ramansdrift

Army Field P.O. 10 Green Point Camp

Army Field P.O. 11 Namies

Army Field P.O. 12 Narries

Army Field P.O. 13 Swakopmund

Army Field P.O. 14 Rondebosch Camp
Subordinate to

Base 2 (O'okiep)

Base 1 (Cape Town)

Base 2 (O'okiep)

F.P.O. 8 (Kakamas)

Base 5 (Walvis Bay)

Base 1 (Cape Town)
Date

13.1.15.

13.1.15.

18.1.15.

18.1.15.

19.1.15.

21.1.15.

\section{CENSORSHIP of OFFICERS' LETTERS.}

The attention of O.C.'s is drawn to the special circular recently issued relative to the censorship of Officers' letters (A.P.O. 435/15).

\section{CENSORSHIP.}

All letters posted by troops in the Field addressed to Editors of Newspapers, should be forwarded under special cover to the Chief Field Censor, Headquarters, Army Post Office, for treatment. (A.P.O. 580/15). 


\section{DRESS.}

In General Orders No. 13 is contained a regulation stating that "Sam Browne" belts should only be worn by officers when they are on duty.

\section{REGISTRATION OF VOTERS - Transvaal Province.}

Provision has been made by the Government for all men who were on Active Service on the 31st December, 1914 who have the necessary qualifications to be registered as voters in the Transvaal, and who are temporary absent from the electoral divisions, to complete forms of claims to be registered as voters.

Every person, thertufore, who is entitled to be registered as a voter in the Transvaal and who was absent temporarily from his electoral division on Active Service on the date of commencement of the Registration, viz., 31st December, 1914, and whose name does not appear on the existing list of voters of his electoral division, should complete a form of claim to be registered as voter, including a proxy authorising any registering officer, or person for the time being acting as such, to sign for him on his behalf, his claim to be registered as a voter under section 6 of the Second Schedule to the Transvaal Constitution Letters Patent, 1906. When completed, the form of claim should be sent to the Magistrate of the district in which the applicant permanently resides.

Form of claims and proxy will be supplied from Headquarters upon request.

It should be noted that form of claim to be registered as a vote in the Transvaal is only to be completed by those persons whose names do not appear on the existing list of voters of their electoral divisions.

J. W. FRENCH, Captain. 


\section{UNION DEFENCE FORCE}

ORDERS NO. 17

\section{ARMY POST OFFICE}

Cape Town,

8th Feby. 1915.

(Orders by Major E. A. Sturman, Director of Postal Services, Officer Commanding, South African Postal Corps.)

\section{DISCHARGE.}

Sgt. C. A. Lanham, Army P.O., Upington, discharged medically unfit 26.1.15.

2. ENROLMENT.

N. H. Smit Regimental Number

23.1.15.

3. PROMOTIONS.

No. 28 Cpl. E. Buckle

No. 23 Cpl. J. P. J. Maloney

No. 29 L/Cpl. W Luing

No. 35

No. 36

No. 41

No. 43

No. 49

No. 50

No. 54

No. 56

No. 72
L/Cpl. R. P. A. Sweet

L/Cpl. C. J. M. Conway

$\mathrm{L} / \mathrm{Cpl}$. W. R. Portingale

L/Cpl. H. Hembury

L/Cpl. R. McIntyre

L/Cpl. G. P. Sumption

L/Cpl. H. G. Matheson

L/Cpl. S. J. Snashall

Pte. N. H. Smit

to be Sergeant
to be Sergeant
to be Corporal
to be Corporal
to be Corporal
to be Corporal
to be Corporal
to be Corporal
to be Corporal
to be Corporal
to be Corporal
to be L/Corporal

1.2 .15

1.2.15.

1.2.15.

1.2.15.

1.2.15.

1.2.15.

1.2.15.

1.2.15.

1.2.15.

1.2.15.

1.2.15.

23.1.15.

4. POSTINGS.

No. $72 \mathrm{~L} / \mathrm{Cpl}$. N. H. Smit - to Base 3, Upington

Capt. W. H. Golby of the 10th Dismounted Rifles, having been seconded for temporary service with the Army Post Office, has been posted to Base 7, Kuruman

5. TRANSFERS.

Rank

Name

From

Cpl.

Goldie, A. W.

$\mathrm{L} / \mathrm{Cpl}$.

Matthews, A. W.

$\mathrm{L} / \mathrm{Cpl}$

O’Connor, G. R.

L/Cpl. Isemonger R. C.

$\mathrm{L} / \mathrm{Cpl}$.

De Gruchy, A. E.
Transferred

To

Base 1, Cape Town.

Base 5,

Walvis Bay.

Base 1, Cape Town.

Base 7,

Kuruman.

Base 4,

Base 1, Luderitzbucht.

Cape Town.

Base 1,

Base 3, Cape Town.

Upington.

Base 1,

Cape Town.

Date

Field P.O. 5, Tempe. 


\section{OPENING OF ARMY POST OFFICE.}

Army Post Office No. 7 was opened at Kuruman 28.1.15.

Army Field Post Office No. 15 subordinate to Army Base Post Office No. 1 Cape Town was opened at Wynberg General (Military) Hospital on 4.2.15. (A.P.O. 925/15).

\section{RETURN OF MAIL MATTER DEALT WITH.}

The attention of Officers in charge of Army Post Offices is directed to the requirement that for one week in every month a numerical count of mail matter dealt with must be sent to this office. The count must consist of (1) letters, (2) post-cards, (3) parcels, (4) other articles, in sub-division of (a) posted, (b) received, (c) received from other offices and despatched. Those offices which failed to take a January count should estimate one on February figures. (A.P.O. 920/15).

\section{DEAD LETTERS.}

It should be noted that until further notice Army Base Offices should not make up returns upon the Returned Letter Office, but, after making the usual endorsement thereon, must send all undeliverable articles to the "Blind" section, Army Base Post Office, No. 1 Cape Town.

The Army Base Post Office, Cape Town, will, for the time being, be the only Army Post Officz to make up returns on the R.L.O. (748/14).

\section{MAIL BAGS.}

Instances have come to notice that Mail Bags or parcel receptacles received in the Army Post Office from Civil Offices have not been promptly returned to the Office from which they were received. There is a shortage of mail bags, etc. in the Civil Administration and the attention of all members of the Corps is drawn to the necessity for prompt return of bags or parcel-baskets to the office from which they were received. (A.P.O. 697/15).

\section{WASTAGE IN MAIL BAGS.}

A serious diminution is observed in the number of Army Mail bags and is believed to arise from two causes viz: the failure to return empties to Base No. 1, and the failure at Army Post Offices to ensure the return by Post Orderlies of bags lent to them for the removal of mail matter from the Army Post Office to the various regiments.

To ensure the due return by Orderlies, a receipt should be taken from them for bags loaned for the purpose mentioned in the foregoing paragraph and suitable steps taken to recover the unreturned sacks.

The bags have to be bought from suppliers and each bag not returned means an actual cash loss.

\section{DELIVERY OF LETTERS.}

The success or otherwise of the work of the South African Postal Corps depends upon the degree in which the Corps is successful in bringing to the hands of intended recipients articles of mail matter which have been consigned to the Army Post Office for delivery.

In a large percentage of cases the addresses given by the senders are not complete, but to return such articles to the senders would give rise to a want of confidence in the resourcefulness, capacity, end efficiency of the Corps. 
It is, therefore, desired that every member of the Regiment will do his utmost to bring about a successful consumation of the duties falling upon the Corps, and that he will take a keen interest in the movements not only of Units, or bodies of men, but, in the movements of as many individuals as possible, as it will often happen that information unofficially obtained will lead to the successful delivery of correspondence.

\section{REDIRECTION.}

Officers in charge of Army Post Offices are informed that individual redirections are now undertaken by the Corps. The requests are to be noted for attention, but as the Army Posi Office is not in a position to guarantee that no article will escape notice and redirection, the applicants should be advised to communicate with their Orderly Rooms, so that mail matter received for them there may be redirected. All applications for redirections of correspondence must be recorded in the proper indexed books which are being issued to each Army Post Office.

\section{3. "COLLECT" TELEGRAMS FROM GERMAN SOUTH-WEST AFRICA.}

On and from the 8th February, collect on delivery radio telegrams and cablegrams (addressed to places within the Union) may be accepted at Luderitzbucht and Walvis Bay (including Swakopmund) respectively, when the sender satisfies the O.C. of the Army Base Post Office that he has not the money to prepay transmission.

The sender's name, rank, company or other items of identification must be obtained by the accepting officer.

All such messages must be classified "Collect."

\section{SOLDIERS CABLEGRAMS.}

The attention of O.C.'s Army Post Offices is drawn to paragraph 216 in General Orders No. 15 issued from Defence Headquarters on the 19th January relative to Soldiers Cablegrams. The accounting arrangements for revenue collected under this head is governed by the instructions laid down in Minute No. A.P.O. $175 / 15$ issued from this office on the 4th January.

\section{ENTERIC FEVER - INOCULATION AGAINST.}

The following excerpt from Permanent Force Orders is reproduced here as showing the importance attached to anti-typhoid inoculation, viz:-

"Any member of the Permanent Force who refuses to be inoculated against Enteric Fever when the opportunity is given either before proceeding or while on active service and who subsequently contracts the disease will forfeit the privilege of nonrecorded sick leave admissable under Clause (IV) of Regulation No. 31 (f) in the case of members of the Permanent Force (Staff) and under Clause (IV) of Regulation No. 7 (g) in the case of members of the Permanent Force (S.A.M.R.). D.H.Q. D.1903 of $15 / 1 / 1915) . "$

16. INSTRUCTIONS APPEARING IN POST OFFICE CIRCULAR NO. 55. DATED THE 1ST INSTANT.

The attention of Officers, N.C.O.'s and men of the Corps is directed to

the following instructions which are printed in the Departmental Circular for February, 1915, namely:- 
Pargf. 5. Packing of Parcels Addressed to Troops in the Field.

Pargf. 6. Free Return to Senders of Undeliverable Parcels Addressed to Troops in the Field.

Pargf. 7. Correspondence Addressed to Rebels.

Pargf. 8. Butter, Eggs and Fish Prohibited from Transmission through the Post.

Pargf. 16. Date-stamping of Neck Labels.

Pargf. 29. Class "Priority" in Certain Telegrams to Luderitz and Walvis.

Pargf. 40. Telegrams Addressed to Troops.

J. W. FRENCH,

Captain. 


\section{UNION DEFENCE FORCE}

ORDERS NO. 18.

\section{ARMY POST OFFICE}

Cape Town,

19th Feby., 1915.

(Orders by Major E. A. Sturman, Director of Postal Services, Officer Commanding, South African Postal Corps.)

1. DISCHARGES.

Cpl. S. J. Snasnall

L/Cpl. N. H. Smit medically unfit

medically unfit
7.2.15. 10.2.15.

13.2.15. 15.2.15.

For record purposes, Capt. W. H. Godby of the 10th Dismounted Rifles has been given the S.A.P.C. regimental number 74, whilst performing duty with the Army Post Office.

3. PROMOTIONS.

$\begin{array}{lll}\text { No. } 73 & \text { P. Kenny } & \text { to be Lance-Corporal } \\ \text { No. } 75 & \text { E. W. Bullard } & \text { to be Lance-Corporal } \\ \text { No. } 76 & \text { W. Hoptrough } & \text { to be Lance-Corporal } \\ \text { No. } 77 & \text { H. H. Dolphin } & \text { to be Lance-Corporal } \\ \text { No. } 78 & \text { C. Stoffberg } & \text { to be Lance-Corporal }\end{array}$

4. POSTINGS.
L/Cpl. P. Kenny
L/Cpl. E. W. Bullard
to Base 1, Cape Town
to Base 1, Cape Town
L/Cpl. W. Hoptrough
to Base 1, Cape Town
L/Cpl. H. H. Dolphin
to Base 1, Cape Town
L/Cpl. C. Stoffberg
to Base 1, Cape Town

9.2.15

14.2.15.

12.2.15.

13.2.15.

15.2.15.

\section{TRANSFERS.}
L/Cpl.
W. F. Moon
Field P.O. 4,
Base 1,
Bloemfontein.
Cape Town.
L/Cpl.
G. C. Glass
Base 1,
Base 5,
Cape Town. Walvis Bay.

From

To

9.2.15.

10.2.15

\section{OPENING AND CLOSING OF FIELD POST OFFICES,}

Subordinate to

Kakamas

Cape Town

Kakamas

Headquarters opened 10.2.15.

opened 12.2 .15

closed 10.2 .15

closed $\quad 18.2 .15$ 


\section{CHANGE OF ADDRESS.}

All concerned are strictly enjoined promptly to notify Headquarters of the change of address of the person to whom they have allotted any civil or military pay. Failure to comply with this instruction may cause delay in payment. The cost of any telegrams which may then be necessitated will be debited to those at fault.

\section{CASH ADVANCES.}

Record of Cash Advances. This form (D.D. 178) is being issued to each member of the Corps, as it is desired that a proper record shall be kept of all advances received.

Army P.O. Special Circular No. 9 is being issued to every member of the Corps. Serious notice will be taken if instructions therein are not complied with. (A.P.O. 200/15).

\section{ARRIVALS AND DEPARTURES.}

The attention of Officers in charge of Army Base and Field Post Offices is again directed to Section 6 of Army P.O. Orders No. 10, and Section 6 of Orders No. 12. To enable complete records to be kept at Headquarters it is particularly necessary that the date and time of arrival and departure of any member of the Army Post Office should be communicated to this office.

\section{REGISTERED LETTER LISTS.}

On and from the 1st proximo, all offices making up registered letter mails on Base 1 should prepare three copies of registered lists, two copies being enclosed with the registered articles in lieu of one as hitherto.

\section{1. "DEAD” LETTERS.}

A case recently came to notice where a member of the Army Post Office endorsed a letter "Deceased" and caused it to be returned to the sender, thereby occassioning the latter unnecessary anxiety, as the addressee was actually alive. Endorsements of such description on mail matter must be made and signed in full by Officer Commanding the Regiment to which the deceased belonged in his lifetime, after which the correspondencz must be sent to the "blind" section of the Army Base Post Office, Cape Town, as laid down in paragraph 8 of Regimental Orders No. 17. $(8673 / 15)$.

\section{FRANKING OF TROOPS LETTERS.}

In future the only superscription on correspondence sent by Troops (excluding telegrams and parcels) necessary to secure free transmission will be the words "On Active Service" or the letters "O.H.M.S." or the equivalent in the Dutch language of either expression. It will not be necessary for the articles to bear the impression of a regimental franking samp, the signature of an officer, nor the writer's name, etc. The correspondence will be transmitted free within the Union, Rhodesia and the Protectorates. (A.P.O. 1067/15).

\section{DELIVERY OF MAIL MATTER.}

Attention is directed to the instruction in paragraph 268 of General Orders No. 18 published on the 9th instant.

Steps should be taken to see that all Units are represented by appointed Post Orderlies, and in those cases where Commanding Officers have failed to observe the instruction their attention should be drawn thereto. 
14. CENSORSHIP.

It is again mentioned that all letters posted by troops addressed to Editors of Newspapers must be forwarded under special cover to the Director. (A.P.O. 185/14).

\section{CENSORSHIP OF TELEGRAMS REPORTING CASUALTIES.}

The attention of Field Censors is directed to the instruction issued in October last, reading as follows:-

"The Minister has instructed all Force Commanders that on no account are telegrams to be despatched from the Field by anybody whosoever giving accounts of persons, wounded or missing."

16. "CASUALTY" TELEGRAMS. relative to:-

Information appeared in the Post Office Circular for February, 1915

(a) Weekend telegrams to and from members of the Union Forces.

(b) Free casualty telegrams.

(c) Casualty telegrams (German South-West Afrca).

The instructions are too long for embodiment in these Orders, but should any office be without, or not have access to a copy of the Circular, application should be made to Headquarters for one.

\section{SALE OF NOTE PAPER AND ENVELOPES TO THE TROOPS.}

An arrangement has been come to with the South African Garrison Institutes whereby the latter will make up envelopes containing a few pages of writing paper to bz sold at a very small cost to soldiers, who, it is thought, will prefer buying such small quantities to carrying about pads of writing paper and envelopes.

For the greater convenience of troops it is desired that they shall be able to obtain these packets at Army Post Offices, and the General Manager of the S.A.G.I. is agreeable to this being done.

O.C.'s Army Post Offices are, therefore, requested to obtain a supply of the packets from the local Institutions and make the necessary financial arrangements with the managers. (A.P.O. 759/15).

\section{REGISTRATION OF VOTERS - Cape of Good Hope Province.}

The attention of all O.C.'s is directed to the provision of paragraph 275 of the General Orders No. 18 published on the 9th instant, and it is requested that the instruction be made known to all men under their control so that men entitled to be registered voters in the Cap's Province may exercise their rights in this respect.

J. W. FRENCH, Captain. 


\title{
UNION DEFENCE FORCE
}

ORDERS NO. 19.

\section{ARMY POST OFFICE}

\author{
Cape Town,
}

3rd March 1915.

(Orders by Major E. A. Sturman, Director of Postal Services, Officer Commanding South African Postal Corps).

\section{APPOINTMENT.}

As Lieutenant, S.A. Field Post and Telegraph Corps:- Johannes Guillaume Steyn, dated 5th February, 1914.

2. ENROLMENTS.

\section{J. Coppens \\ H. C. Urry \\ S. Carnaby \\ T. L. Kok}

Regimental Number 80.

Regimental Number 81 .

Regimental Number 82 .

Regimental Number 83.
18.2.15.

19.2.15

22.2.15.

25.2.15

\section{PROMOTIONS.}

No. 10, Lieut. J. F. Tierney is granted the temporary rank of Captain, dated 5th February, 1915.

$\begin{array}{lll}\text { No. } 24 & \text { L/Cpl. H. E. Duck } & \text { to be Corporal } \\ \text { No. } 80 & \text { J. Coppens } & \text { to be L/Corporal } \\ \text { No. } 81 & \text { H. C. Urry } & \text { to be L/Corporal } \\ \text { No. } 82 & \text { S. Carnaby } & \text { to be L/Corporal } \\ \text { No. } 83 & \text { T. L. Kok } & \text { to be L/Corporal }\end{array}$

25.2.15.

4. POSTINGS.

No. 79 Lieut J. G. Steyn to Army P.O., Base 1, C.T. 11.2.15.

No. 80 L/Cpl. J. Coppens to Army P.O., Base 1, C.T. 18.2.15.

No. 81 L/Cpl. H. C. Urry to Army P.O., Base 1, C.T. 19.2.15.

No. 82 L/Cpl. S. Carnaby to Army P.O., Base 1, C.T. 22.2.15.

No. 83 L/Cpl. T. L. Kok to Army P.O., Base 1, C.T. 25.2.15.

\section{TRANSFERS.}

Rank

Capt.

Lieut.

Sergt.

Sergt.

Corpl.

Corpl.

$\mathrm{L} / \mathrm{Cpl}$.

$\mathrm{L} / \mathrm{Cpl}$.

$\mathrm{L} / \mathrm{Cpl}$.

$\mathrm{L} / \mathrm{Cpl}$.

L/Cpl.

$\mathrm{L} / \mathrm{Cpl}$.

$\mathrm{L} / \mathrm{Cpl}$.

$\mathrm{L} / \mathrm{Cpl}$.

Pte.
Name

Tierney, J. F.

Wannell, C. W.

Maloney, J. P. J.

Stanley, A. C.

Sweet, E. P. A.

Sumption, G. J.

Dolphin, H. H.

Dowling, $\mathbf{M}$.

Haagmer, H. E.

Hoptrough, W.

Palmer, H. J.

Prime, F. F.

Thompson, P.

Thompson, $\mathrm{P}$.
Morison, J. W. A.
From

Cape Town

De Aar

Bloemfontein

Luderitzbucht

Kakamas

Cape Town

Cape Town

Kakamas

Cape Town

Cape Town

Kakamas

Cape Town

Bloemfontein

Tempe

Cape Town
To

Luderitzbucht

Narries

Tempe

Cape Town

Narries

Walvis Bay

De Aar

Upington

Walvis Bay

Kuruman

Schuit Drift

Luderitzbucht

Tempe

Kuruman

Luderitzbucht
Date

28.2.15.

2.3.15.

19.2.15.

2.3.15.

1.3.15.

21.2.15.

2.3.15.

1.2.15.

28.2.15.

26.2.15.

10.2.15.

21.2.15.

6.2.15.

21.2.15.

21.2.15. 


\section{OPENING AND CLOSING OF FIELD POST OFFICES}

\begin{tabular}{lllll}
\multicolumn{5}{c}{ Subordinate to } \\
No. 12 & Narries & Headquarters & reopened & 1.3.15.( 189/15). \\
No. 18 & Garub & Luderitzbucht & opened & 23.2.15.(1395/15.) \\
No. 20 & Nonidas & Walvis Bay & opened & 26.2.15.(1543/15). \\
No. 8 & Kakamas & Headquarters & $\begin{array}{l}\text { temp. } \\
\text { closed }\end{array}$ & 28.2.15.(1544/15).
\end{tabular}

\section{MAIL BAG SHORTAGE.}

Adverting to paragraph 10 of Orders No. 17. The shortage in Army P.O. mail bags is serious although fresh purchases are being constantly made. Will every officer give this matter his earnest attention and take whatever steps he can to prevent any loss of bags taking place. (A.P.O. 697/15).

\section{DELIVERY OF MAIL MATTER.}

The attention of all concerned is directed to the instruction contained in paragraph 268 of General Orders No. 18 published on the 9th ultimo.

Steps should be taken to verify that all Units are represented by duly appointed Post Orderlies and in these Cases where O.C.'s of Units have failed to observe the instruction their attention should be drawn to its existence.

\section{ACTIVE SERVICE POST-CARDS.}

Officers and N.C.O.'s in charge of Base and Field Post Offices should exhibit a bilingual notice informing troops that active service post-cards may be obtained free of charge on application. Stocks of these cards should be kept up. (A.P.O. 357/14).

\section{MODEL ADDRESS HAND-BILLS.}

Hand-bills in English and Dutch are being issued for the purpose of being filled in and sent by troops to their friends and correspondents. It is hoped that the use of the bills will be the means of preventing any ambiguous direction of letters for Troops in future. Officers and N.C.O.'s in charge of Base and Fieid Post Offices should liberally distribute the forms and assist men in filling them in so that the desired result may be arrived at. (A.P.O. 744/15).

\section{WEEKLY JOURNAL OF PROCEEDINGS.}

It is observed that returns on Form S.88. are not being regularly made.

All Officers and N.C.O.'s in charge of Base or Field Post Offices should submit through their Base or to Headquarters when not subordinate to any Base F.O. a weekly report on proceedings, commencing on Surday and terminating on Saturday. Where no Forms S.88. are held they should be requisitioned for.

\section{REGISTRATION OF VOTERS - Cape Province.}

The attention of all O.C.'s is directed to the provisions of paragraph 275 of General Orders No. 18 published on the 9th ultimo, and it is requested that the instruction be made known to all men under their control so that men entitled to be registered as voters in the Cape Province may exercise their rights in this respect. 


\section{GENERAL ORDERS.} Orders.

The attention of O.C.'s is directed to the following paragraphs in General

No. 19 para. 286. Delivery of Postal Matter.

No. 19 para. 292. Reporting Casualties.

No. 20 para. 307. Franking of Letters. (This paragraph is inadequate in that it lacks the instruction that the Dutch equivalents of "On Active Service" and of the letters "'O.H.M.S." are equally admissible.

No. 20 para. 318. Economy in the use of Stationery.

No. 20 para. 320. Registration of diamonds found in German SouthWest Africa.

J. W. FRENCH,

Captain. 


\section{ILLUSTRATIONS}

(covering the contents of Militara 2/5 and Militaria 2/6)

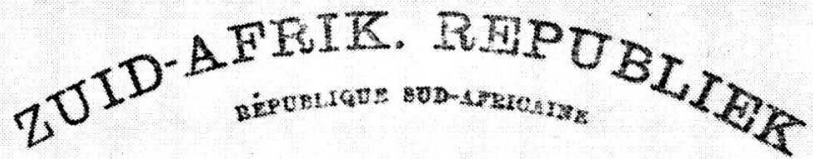

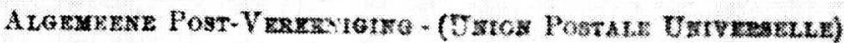

BRIEFKAART

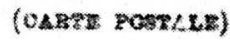

Notratera.

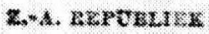
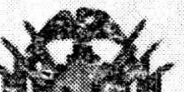

1)

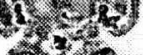

$3 x^{2}$

$\therefore 1$ taxt.

$\mathscr{C}$

Staatsdrukkerij te velde, Machadodorp, Z-A. R.

Post card for civil use in Machadodorp, printed in 1900 on responsibility of the Department of Posts and Telegraphs of the South African Republic, by the Government Printer in the field.

Collection: Comdt. Jan Ploeger

Photograph: Central Photographic Establishment, A.F.B. Swartkop

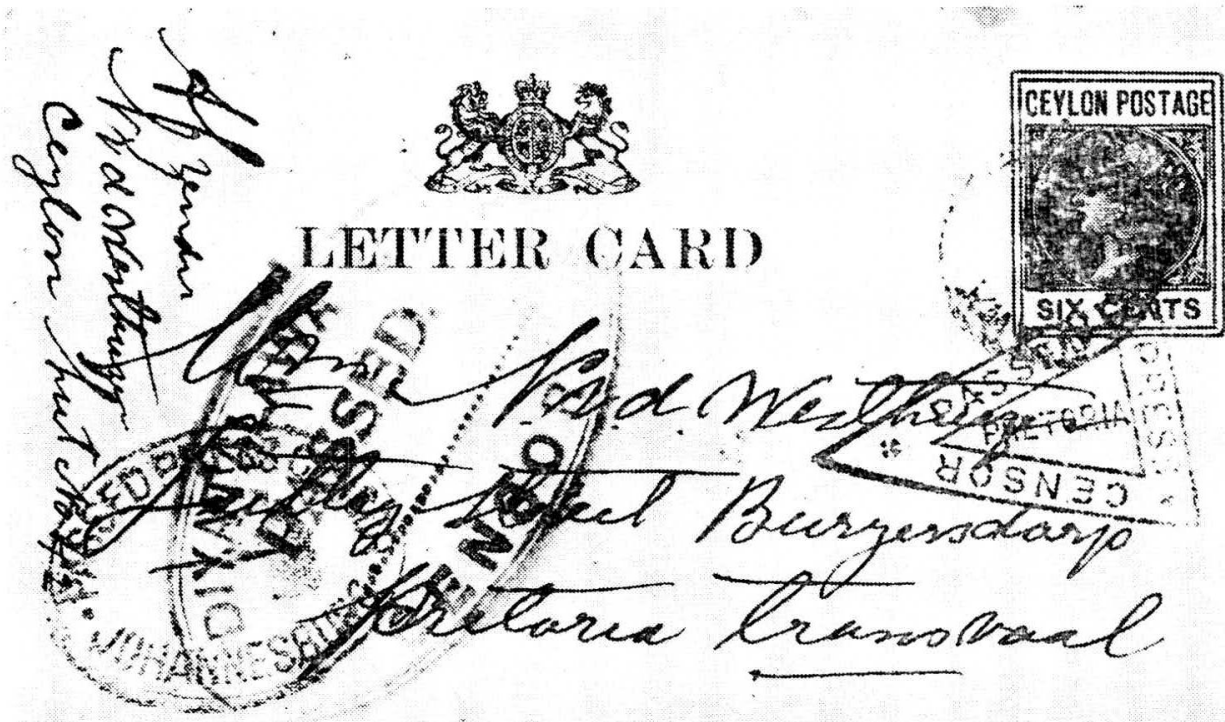

Post card sent by a Boer prisoner of war (Ceylon) to relatives in South Africa during the Anglo Boer War. Note the three censor's stamps (Diyatalawa, Johannesburg, Pretoria). 


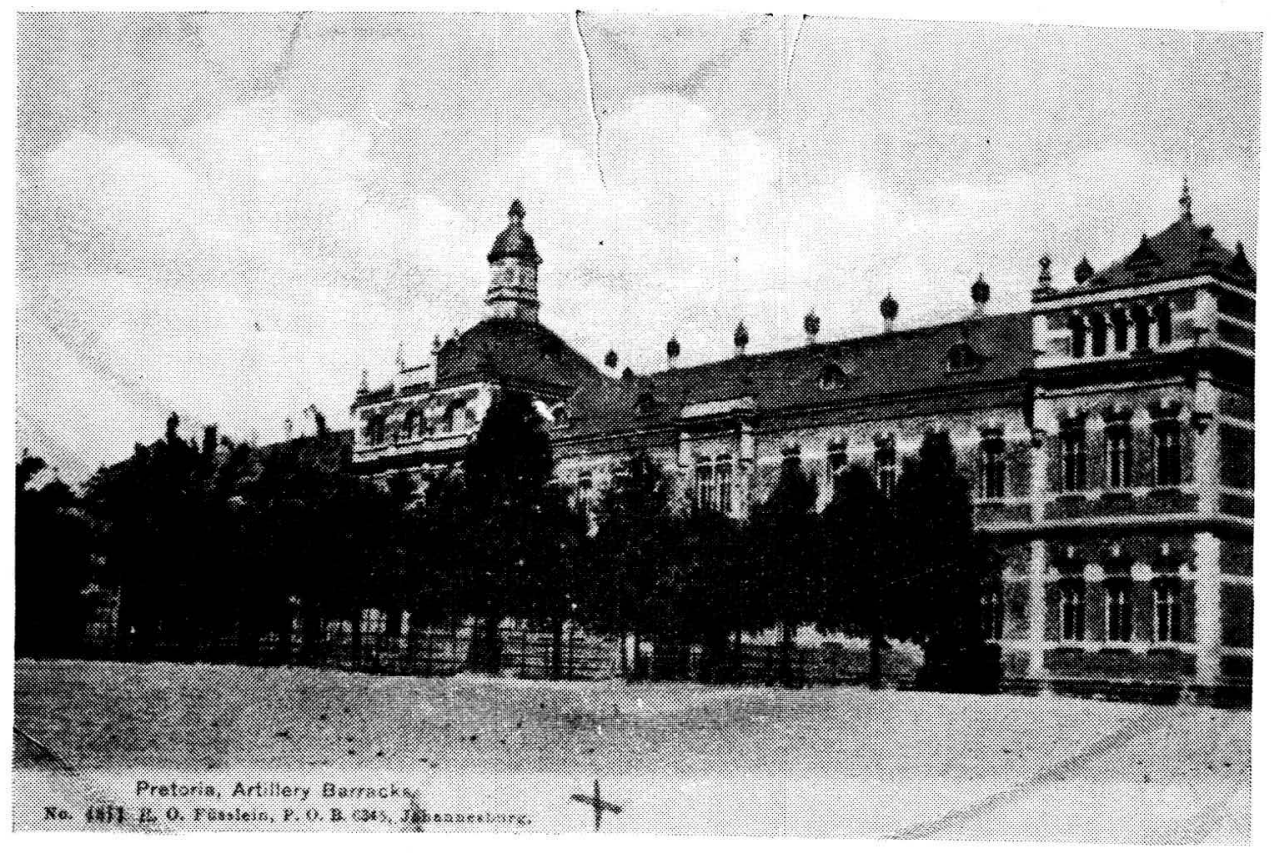

Photograph of the oldest part of the present Defence Headquarters, Potgieter Street, Pretoria. Taken before 1910.

Collection: Comdt. Jan Ploeger

Photograph: Central Photographic Establishment, A.F.B. Swartkop

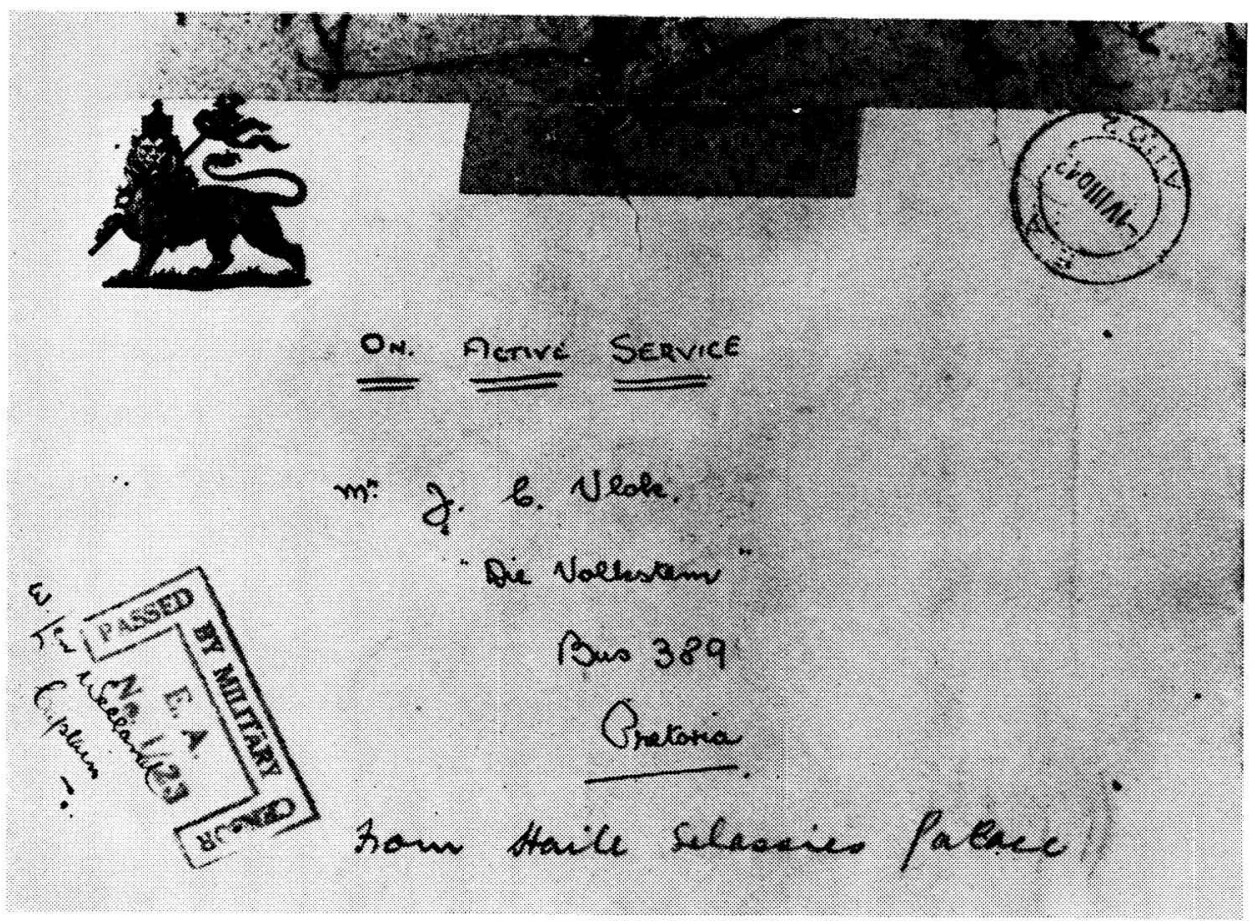

This envelope which was stamped by A.P.O. 2, East Africa, and which was passed by the military censor E.A. No. $1 / 23$, comes from th: palace of Haile Selassie, Addis Ababa. 


\section{POSTE DE PRISONNIER \\ DE GUERRE \\ (P. O.W. Post) \\ P. O. W. POS?}

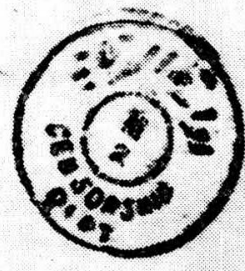

SOUWH ARRIGAN RED CROSS

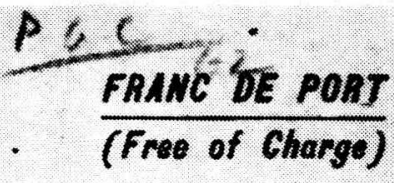

POSTAGE Fı.SE
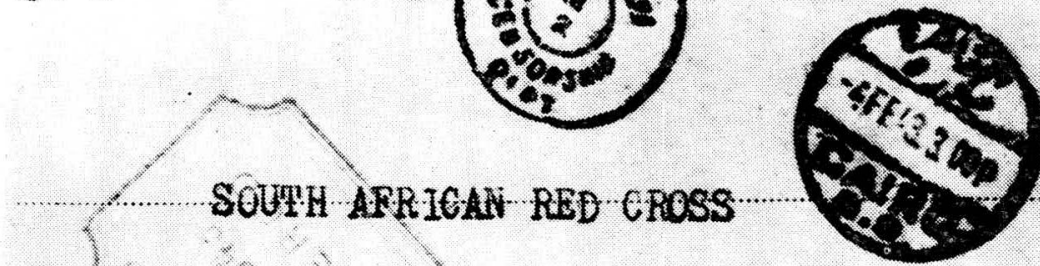

P.. . B. .87.26,

J O.HAN.N.S.R.R G. South Africs.

An example of prisoner-of-war mail, stamped by the censor, and dated Cairo 4th February, 1943; received and answered in Johannesburg on 19th April, 1943.

Collection: Comdt. Jan Ploeger

Photograph: Central Photographic Establishment, A.F.B. Swartkop

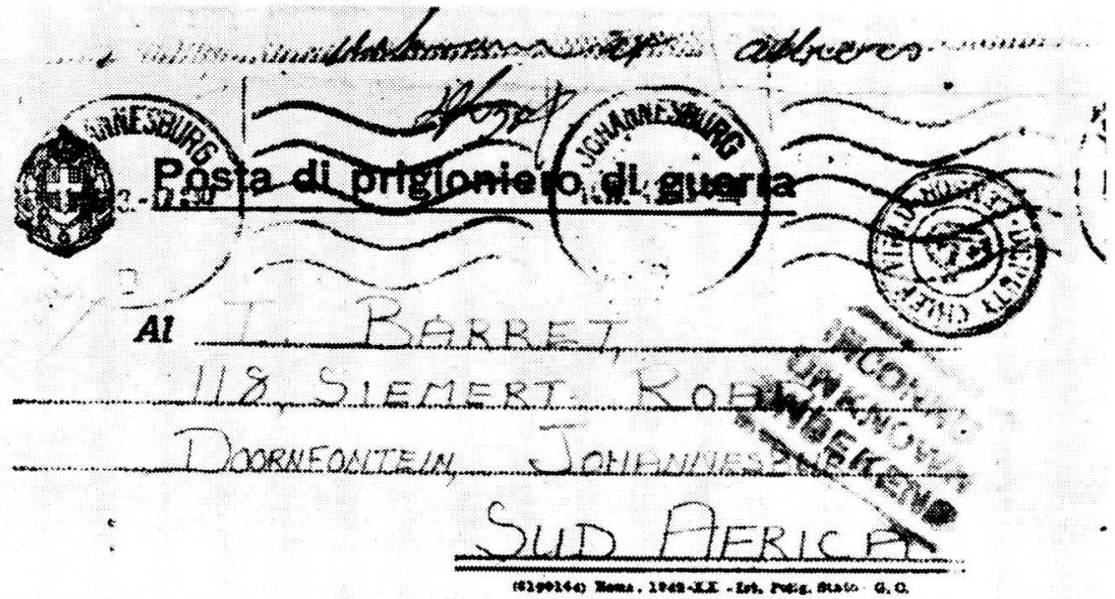

Example of an Italian prisoner-of-war mail article which was stamped as undeliverable. 


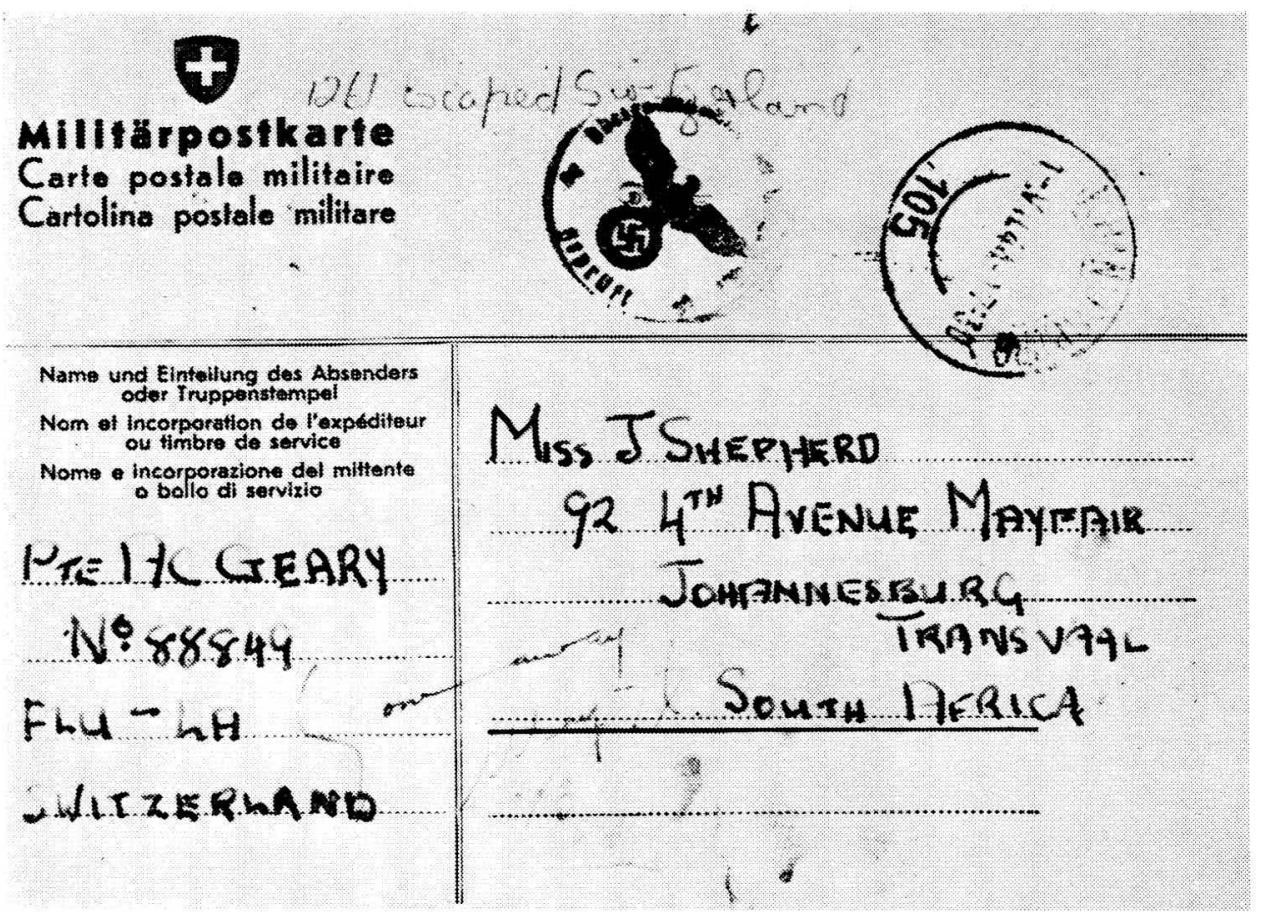

A Swiss military post card, with a German military censor's stamp, coming from a South African prisoner-of-war who succeeded in escaping to Switzerland.

Collection: Comdt. Jan Ploeger

Photograph : Central Photographic Establishment, A.F.B. Swartkop

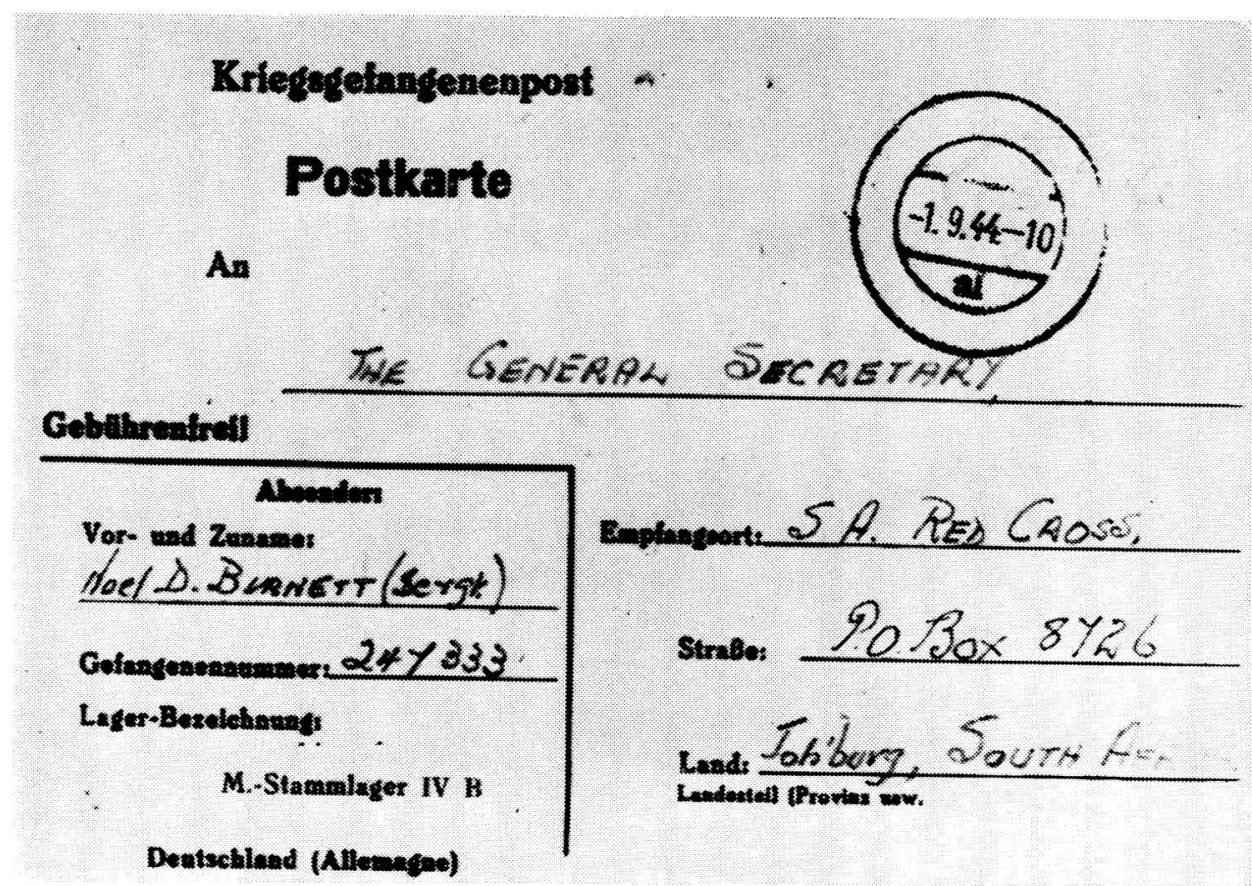

An example of German prisoner-of-war mail (1944). The post card was sent by a South African prisoner-of war to the South African Red Cross, Johennesburg. 


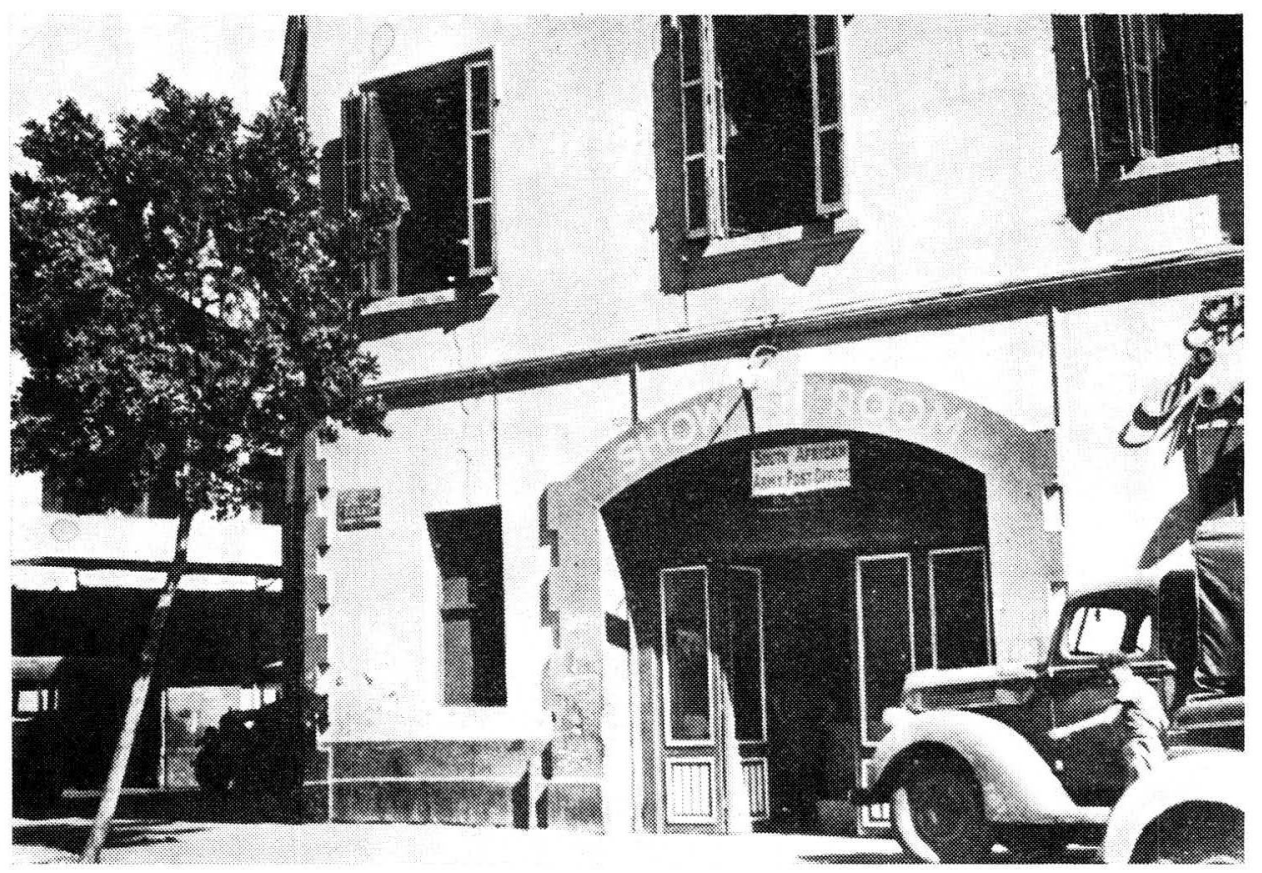

A South African Army Post Office, Cairo.

Collection: Military Historical and Archivale Services (M.H.A.S.)

Photograph: Central Photographic Establishment, A.F.B. Swartkop

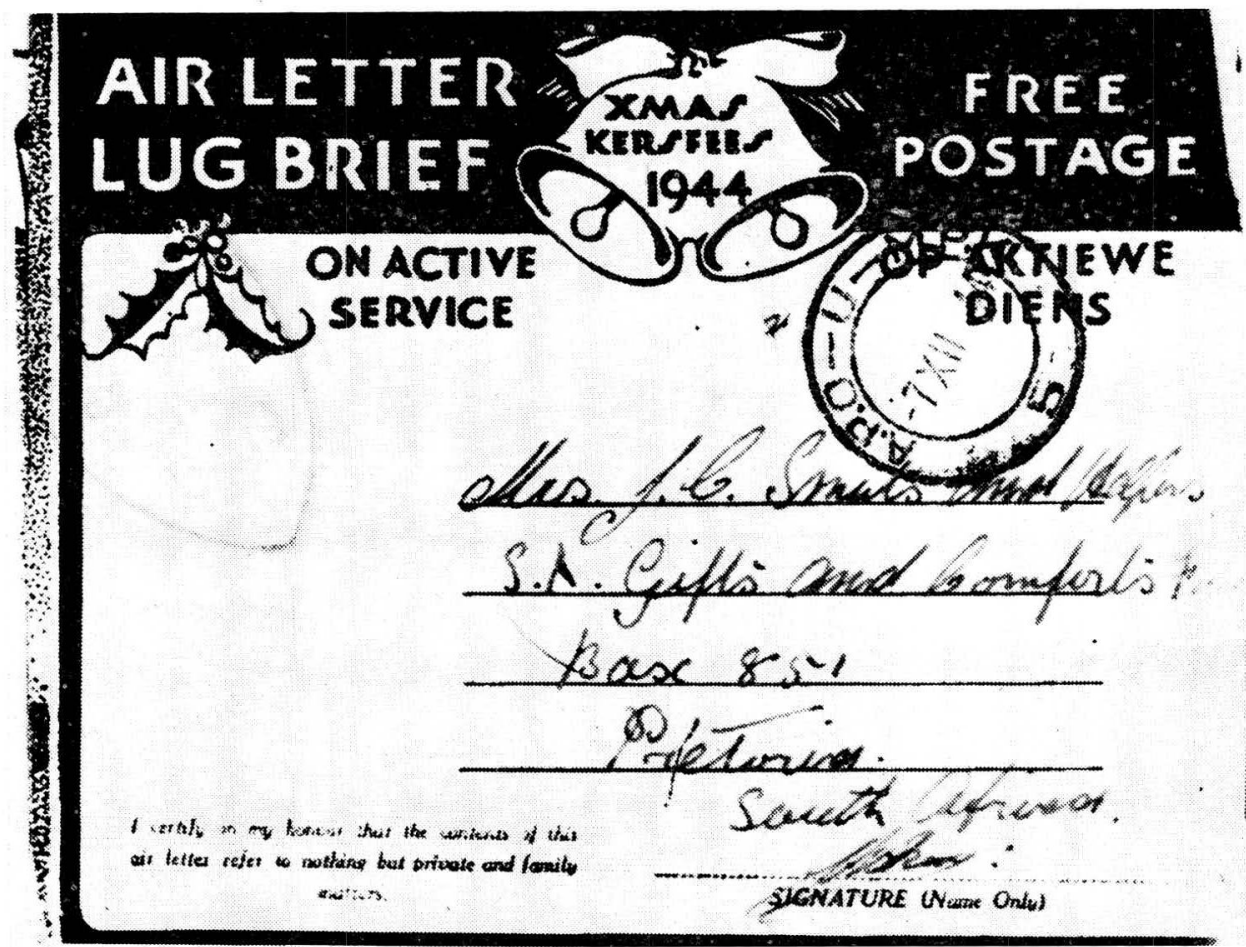

Before Christmas 1944, U.D.F. members on active service were given the opportunity to send air-mail letters free of charge. 


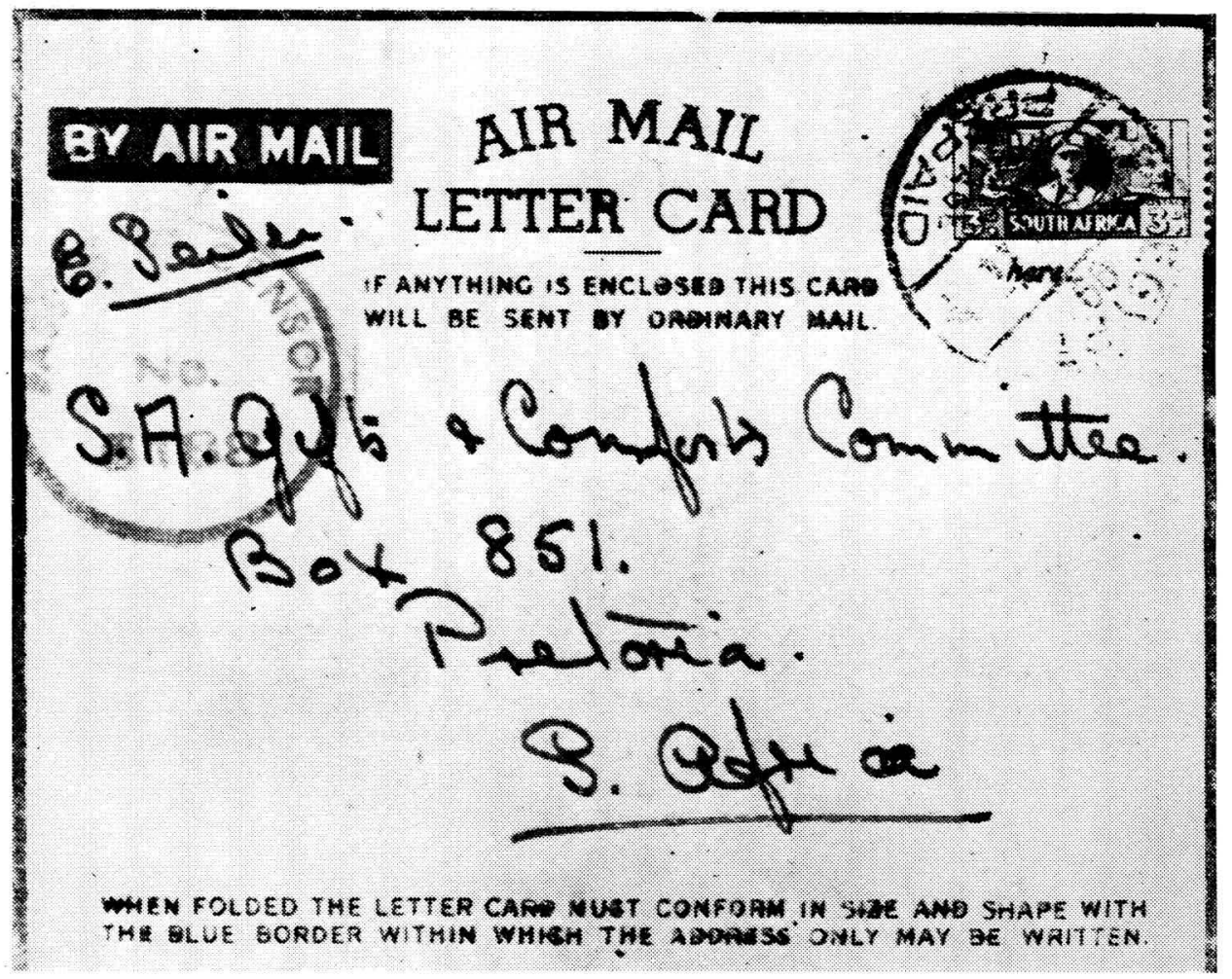

Two different kinds of South African military mail articles. A letter card and an air-mail letter.

\section{Collection: Comdt. Jan Ploeger \\ Photograph: Central Photographic Establishment, A.F.B. Swartkop}

\section{BYY AIR. MAIL}

AIR LETTER if intivine is wateras TH: 4 का

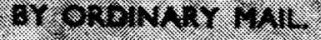

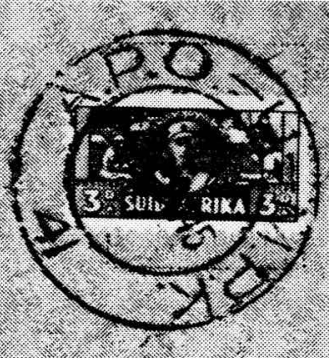




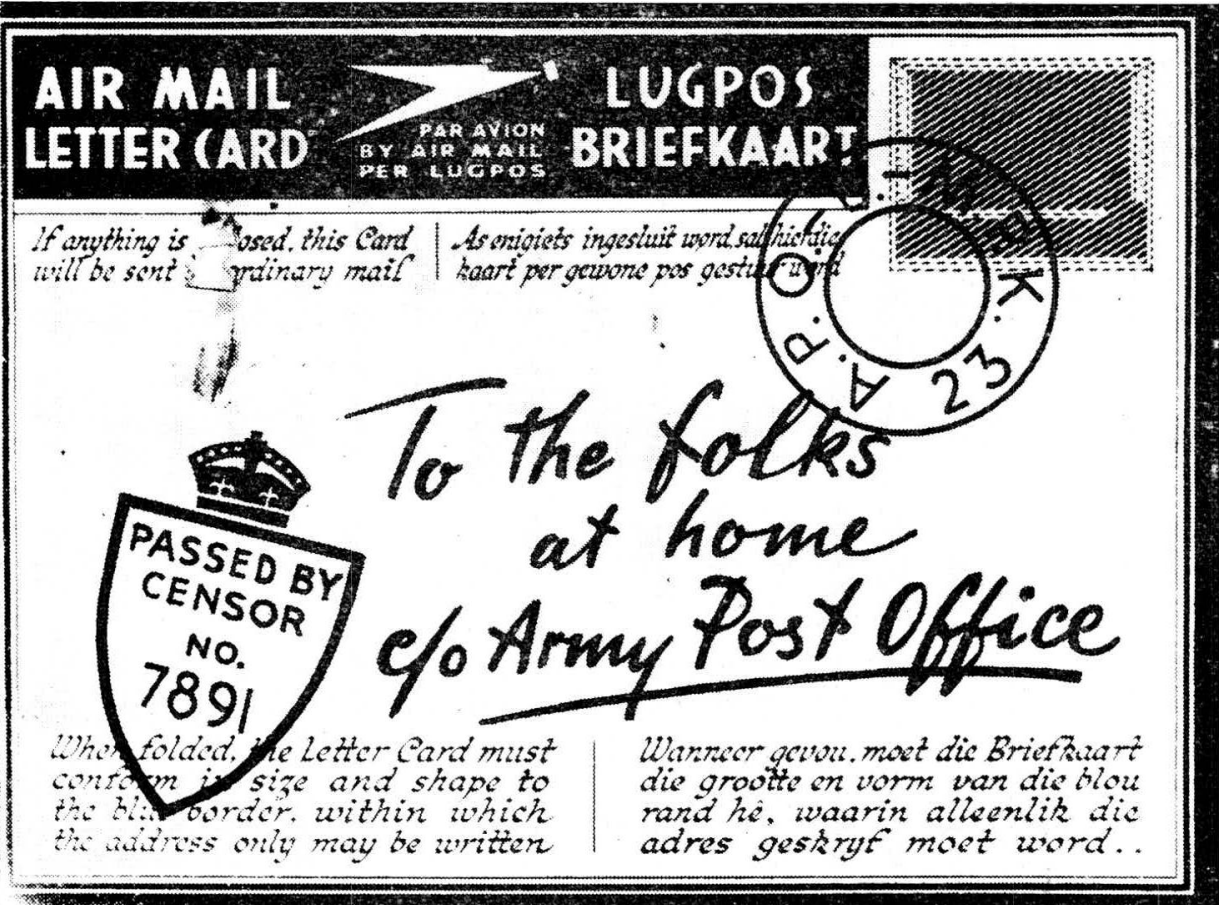

An example of an advertisement issued by the South African Military Postal Service.

\section{Collection: Comdt. Jan Ploeger \\ Photograph: Central Photographic Establishment, A.F.B. Swartkop}
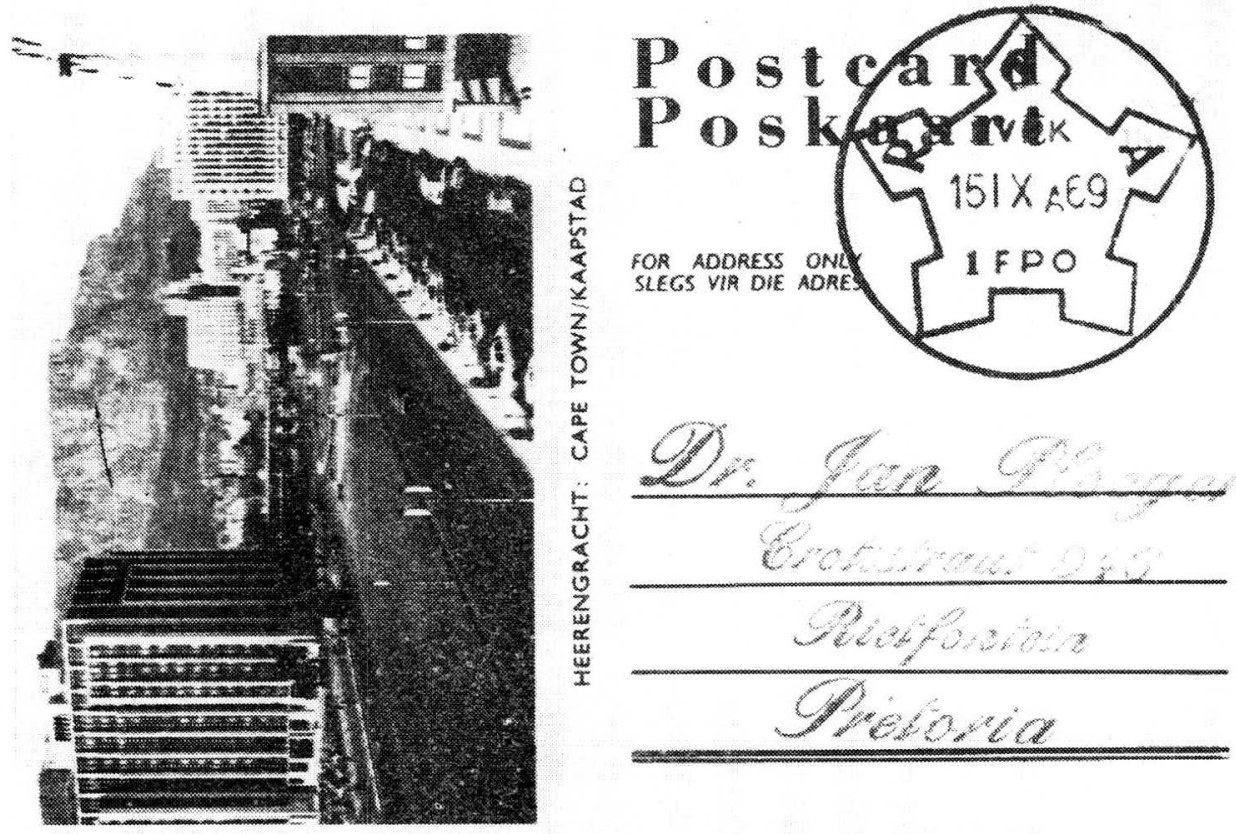

An example of stamping (15.1.1969) by 1 Field Post Office, South African Defence Force. Note the ground-plan of the Castle, Cape Town and the abbreviations R. S.A., V.P.K., F.P.O. 


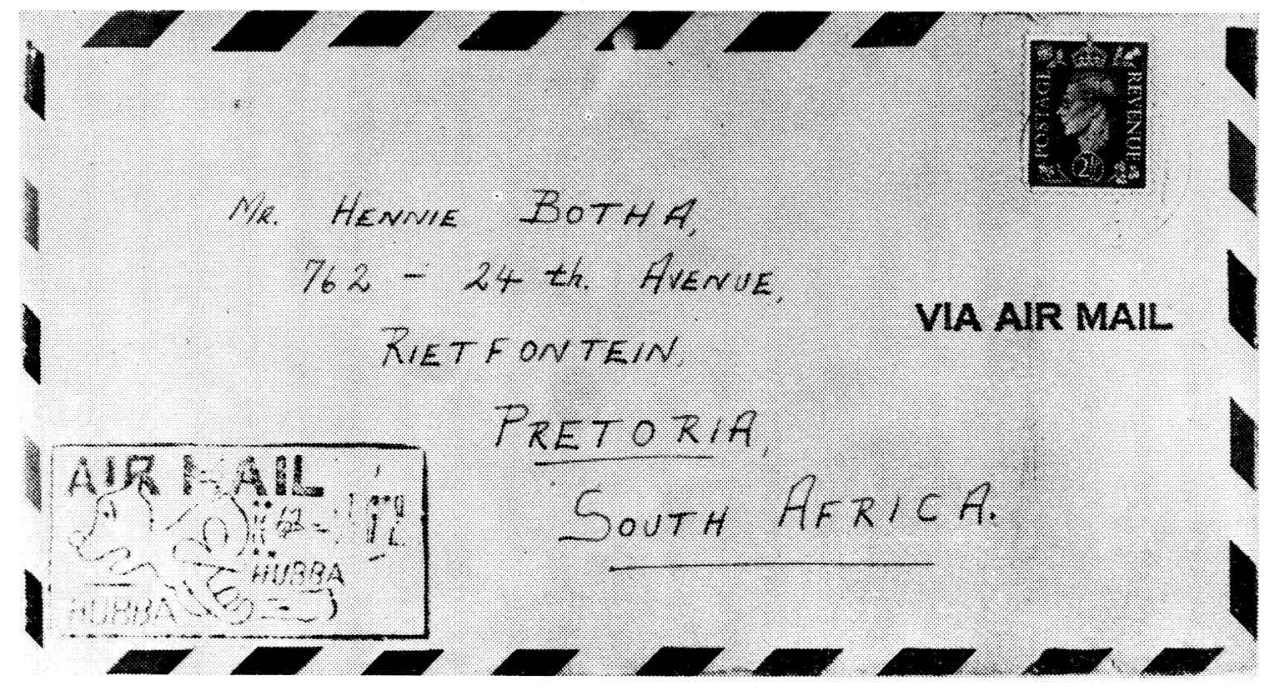

Air-mail letter posted during the Korean War by Lt. M. C. Botha, No. 2 Squadron South African Air Force, at S.A.P.O. 4301, Far East.

Collection: Col. H. J. Botha.

Photograph: Central Photographic Establishment. A.F.B. Swartkop 